\title{
Specific Antagonism of Enteric Neural Serotonin Receptors by Dipeptides of 5-Hydroxytryptophan: Evidence that Serotonin Is a Mediator of Slow Synaptic Excitation in the Myenteric Plexus ${ }^{1}$
}

\author{
MIYAKO TAKAKI, ${ }^{2}$ THERESA BRANCHEK, HADASSAH TAMIR, AND MICHAEL D. GERSHON ${ }^{3}$ \\ Department of Anatomy and Cell Biology, Columbia University College of Physicians and Surgeons, New York, New York 10032
}

\begin{abstract}
Research on the role of serotonin (5-hydroxytryptamine, 5 $H T$ ) in the function of the enteric nervous system has been impeded by the lack of specific inhibitors of the enteric neural actions of 5-HT. Saturable, reversible, high affinity enteric binding sites for ${ }^{3} \mathrm{H}-5-\mathrm{HT}$ have recently been characterized and radioautographically located. Affinity for the ${ }^{3} \mathrm{H}-5-\mathrm{HT}$ binding site requires an indole ring substituted with a free hydroxyl group. These ${ }^{3} \mathrm{H}-5-\mathrm{HT}$ binding sites have been proposed to be enteric neural 5-HT receptors. This hypothesis was tested in the current study by comparing the ability of compounds to inhibit the binding of ${ }^{3} \mathrm{H}-5-\mathrm{HT}$ with their electrophysiologically determined actions on myenteric neurons. 5-Methoxytryptamine did not inhibit the binding of ${ }^{3} \mathrm{H}-5-\mathrm{HT}$ to enteric membranes and neither mimicked nor antagonized the effects of 5-HT on the membrane potential of myenteric neurons. Two dipeptides of $\mathbf{5}$-hydroxytryptophan, $\mathbf{N}$-acetyland $\mathbf{N}$-hexanoyl-5-hydroxytryptophyl-5-hydroxytryptophan amide (5-HTP-DP and $N$-hex-5-HTP-DP) inhibited the binding of ${ }^{3} \mathrm{H}-5-\mathrm{HT}\left(K_{1}=0.25 \mu \mathrm{M}\right.$ for 5-HTP-DP and $1.19 \mu \mathrm{M}$ for $N$-hex5-HTP-DP). 5-HTP-DP applied by pressure microejection or superfusion (10 $\mu \mathrm{m}$ ) antagonized the slow postsynaptic depolarization of myenteric neurons evoked by microejection of 5-HT. 5-HTP-DP also blocked the 5-HT-induced presynaptic reduction in amplitude of nicotinic fast synaptic potentials; however, 5-HTP-DP itself did not affect these responses. Moreover, 5-HTP-DP also failed to affect responses of myenteric neurons to microejected substance $P$, their muscarinic response to acetylcholine, or antidromic action potentials. In contrast, both dipeptides blocked the slow synaptic potentials seen in type II/AH neurons following
\end{abstract}

Received September 4, 1984; Revised December 6, 1984; Accepted December 7, 1984

'This work was supported by Grants NS12969 and NS15547 of the National Institutes of Health, National Institutes of Mental Health Grant NIMH 37575, and a Pharmaceutical Manufacturers Association Foundation fellowship to T. B. We thank Drs. Meir Wilchek, Hiroshi Ueno, and Shabbir A. Khan for their generous help in synthesizing and supplying $N$-acetyl-5-hydroxytryptophyl-5-hydroxytryptophan amide. We also wish to acknowledge the help provided by Ms. Valerie Boone in doing radioligand binding assays. We especially wish to thank Dr. Steven Erde for his critical reading of the manuscript and his expert assistance in electrophysiology.

${ }^{2}$ Present address: Department of Physiology, Okayama University Medical School, 2-5-1 Shikata-cho, Okayama 700, Japan.

${ }^{3}$ To whom correspondence should be addressed, at the Department of Anatomy and Cell Biology, Columbia University, College of Physicians and Surgeons, 630 West 168th Street, New York, NY 10032. stimulation of fiber tracts in interganglionic connectives. These data support the hypotheses that enteric ${ }^{3} \mathrm{H}-5-\mathrm{HT}$ binding sites are enteric neural 5-HT receptors, that dipeptides of 5-hydroxytryptophan are specific antagonists at these receptors, and that 5-HT is one of the mediators of slow synaptic potentials in the myenteric plexus.

Receptors for serotonin (5-hydroxytryptamine, 5-HT) in the gut were first classified as $M$ or $D$ receptors by Gaddum and Picarelli (1957). Responses to 5-HT mediated by M receptors were defined as those blocked by morphine, and $\mathrm{D}$ receptor-mediated responses were defined as those blocked by dibenzyline (phenoxybenzamine). These agents are not specific antagonists of 5-HT. Morphine, for example, probably blocks the contraction of the gut in response to addition of $5-\mathrm{HT}$ by inhibiting the release of acetylcholine (ACh) from the final common excitatory neurons activated by 5-HT (Paton, 1957; Schaumann, 1957). 5-HT contracts the gut through the release of ACh (Vizi and Vizi, 1978). Nevertheless, the M receptors are probably entirely neural, whereas the D receptors for $5-\mathrm{HT}$ are on the smooth muscle (Gaddum and Picarelli, 1957; Brownlee and Johnson, 1963; Gyermek, 1966; Drakontides and Gershon, 1968; Fozard and Mobarok Ali, 1978). M receptors are thus found in myenteric and submucosal ganglia, both of which respond to 5-HT (Hirst and Silinsky, 1975; Wood and Mayer, 1979b; Johnson et al., 1980b), and on mucosal afferent nerves that initiate the peristaltic reflex (Bülbring and Crema, 1958; Bülbring and Lin, 1958).

Previous experiments have led to the description of high affinity, saturable, reversible binding sites for ${ }^{3} \mathrm{H}-5-\mathrm{HT}$ in enteric membranes (Branchek et al., 1984). Because of the similarity between the structural requirements of analogues for affinity to the ${ }^{3} \mathrm{H}-5-\mathrm{HT}$ binding sites and those for pharmacological activity at $M$ receptors, it was proposed that the ${ }^{3} \mathrm{H}-5-\mathrm{HT}$ binding sites were in fact $\mathrm{M}$ receptors for $5-\mathrm{HT}$. These sites were subsequently localized in tissue by radioautography and were found in enteric ganglia and at the mucosal-submucosal junction (possibly in mucosal nerves and submucosal ganglia) but not in smooth muscle. The tissue localization of the ${ }^{3} \mathrm{H}-5-\mathrm{HT}$ binding sites thus is appropriate for $\mathrm{M}$ and not $\mathrm{D} 5$ $\mathrm{HT}$ receptors and supports the proposal that the high affinity binding sites for ${ }^{3} \mathrm{H}-5-\mathrm{HT}$ in the gut are $\mathrm{M}$ receptors

The ${ }^{3} \mathrm{H}-5-\mathrm{HT}$ binding sites (and $\mathrm{M}$ receptors) are quite different from either of the main classes of 5-HT receptor known from work on the CNS. The CNS $\mathrm{S}_{1}$ receptor for $5-\mathrm{HT}$ has a high affinity for ${ }^{3} \mathrm{H}$ 5-HT and also for $d$-lysergic acid diethylamide ( $d$-LSD) (Bennett and Snyder, 1976; Peroutka and Snyder, 1979). The CNS S 2 receptor for $5-\mathrm{HT}$ has a low affinity for ${ }^{3} \mathrm{H}-5-\mathrm{HT}$ but a high affinity for $d$-LSSD and drugs such as spiroperidol and ketanserin (Peroutka and Snyder, 1979; Leysen et al., 1982). Spiroperidol can also be used to differentiate subtypes of the $S_{1}$ receptor (Pedigo et al., 1981). Enteric ${ }^{3} \mathrm{H}$ 5-HT binding sites appear to have little or no affinity for $d$-LSD, spiroperidol, or ketanserin (Branchek et al., 1984). In addition, neither 
the enteric high affinity binding of ${ }^{3} \mathrm{H}-5-\mathrm{HT}$ nor the activity of $5-\mathrm{HT}$ at $M$ receptors is antagonized by classical 5-HT antagonists such as methysergide (Costa and Furness, 1979a, b; Branchek et al., 1984). The lack of a good antagonist for the enteric neural actions of 5-HT has greatly impeded research into the physiological role of 5-HT in the gut (Costa and Furness, 1979a, b).

In order to confirm further that the enteric, high affinity ${ }^{3} \mathrm{H}-5-\mathrm{HT}$ binding sites are $\mathrm{M}$ receptors, we have begun to compare molecular structural requirements needed for compounds physiologically to act as agonists or antagonists at 5-HT $M$ receptors with those needed for compounds to displace ${ }^{3} \mathrm{H}-5-\mathrm{HT}$ from enteric ${ }^{3} \mathrm{H}-5-\mathrm{HT}$ binding sites. Untortunately, 5-HT has many ditterent actions in the enteric nervous system (ENS) (Wood and Mayer, 1979b; Johnson et al., 1980b), producing effects, such as those on ACh release, which may be opposite at different sites. 5-HT can presynaptically inhibit ACh release (North et al., 1980), but its net integrated effect is to release ACh (Vizi and Vizi, 1978); thus, when whole gut is studied, the actions of 5-HT, its agonists, and antagonists are complex (Costa and Furness, 1979b). The actions of drugs and 5 HT on myenteric neurons were therefore studied with intracellular recordings. In particular, two novel dipeptides of 5-hydroxytryptophan, $N$-acetyl-5-hydroxytryptophyl-5-hydroxytryptophan amide (5HTP-DP) and $N$-hexanoyl-5-hydroxytryptophyl-5-hydroxytrytophan amide ( $N$-hex-5-HTP-DP) (Fig. 1) were evaluated in some detail as potential 5-HT M receptor agonists or antagonists. These compounds have previously been shown to inhibit the binding of $5-\mathrm{HT}$ to its intraneuronal binding prolein (SBP) (Tarmir and Wilchek, 1979) and to be analgesic (Tamir et al., 1979). The substitutions on the amino and carboxyl groups of these dipeptides confer resistance to hydrolysis by enteric peptidases. The compounds are thus stable when incubated with homogenates of gut (Tamir and Wilchek, 1979). Parallel studies were done both with radioligand filtration binding assays and by radioautography to evaluate the ability of these dipeptides to antagonize the binding of ${ }^{3} \mathrm{H}-5-\mathrm{HT}$ to enteric membranes.<smiles>CC(=O)NC(Cc1c[nH]c2ccc(O)cc12)C(=O)NC(Cc1c[nH]c2ccc(O)cc12)C(N)=O</smiles><smiles>CCCC(=O)NC(Cc1c[nH]c2ccc(O)cc12)C(=O)NC(Cc1c[nH]c2ccc(O)cc12)C(N)=O</smiles>

N-hex-5-HTP-DP

Figure 1. Structures of N-acetyl-5-hydroxytryptophyl-5-hydroxytryptophan amide (5-HTr-DP) and $N$-hexanoyl-5-hydroxytryptophyl-5-hydroxytryptophan amide ( $N$-hex-5-HTP-DP).
One potential agonist, 5-methoxytryptamine (5-MEOT) was also investigated. This compound is of interest because it has been reported to be an $\mathrm{M}$ receptor agonist in the gut (Fozard and Mobarok Ali, 1978), and it displays affinity for CNS S $5-H T$ receptors (Nclson et al., 1981; Fuller, 1984). Nevertheless, 5-MEOT does not antagonize binding of ${ }^{3} \mathrm{H}-5-\mathrm{HT}$ to enteric membranes (Branchek et al., 1984); consequently, 5-MEOT presents a good test of the hypothesis that enteric ${ }^{3} \mathrm{H}-5-\mathrm{HT}$ binding sites are $\mathrm{M}$ receptors. The inability of 5 MEOT to block ${ }^{3} \mathrm{H}-5-\mathrm{HT}$ binding would lead to the prediction that it would neither mimic nor block the action of 5-HT on myenteric neurons. Tryptamines active at $M$ receptors must be substituted with a tree hydroxyl group on the indole ring (Gyermek, 1966; Drakontides and Gershon, 1968; Fozard and Mobarok Ali, 1978; Branchek et al., 1984; Gershon et al., 1984b).

Finally, the action of the dipeptides was evaluated on slow excitatory postsynaptic potentials (EPSPs) in myenteric neurons evoked by repetitive stimulation of interganglionic fiber tracts. 5-HT has been postulated to be a mediator of this response (Wood and Mayer, 1979b). This postulate is not universally accepted, and substance $P$ (Katayama and North, 1978; Morita et al., 1980; Johnson et al., 1981; Bornstein et al., 1984) and ACh (North and Tokimasa, 1982) have also been proposed as mediators of slow synaptic responses in the myenteric plexus. An evaluation of the effect of potential 5-HT $M$ receptor antagonists on slow EPSPs, therefore, provides (if independent evidence for specificity of the compounds can be obtained) a test of the hypothesis that 5-HT is one of the mediators of the response. If the slow EPSP is antagonized by the compounds, moreover, an indication will be obtained of the effectiveness of the potential antagonists against endogenously released $5-\mathrm{HT}$. Preliminary reports of some of these observations were presented at the IUPHAR Ninth International Congress of Pharmacology (Gershon et al., 1984a) and the Third Biennal Meeting of the American Motility Society (Takaki et al., 1984).

\section{Materials and Methods}

Binding of ${ }^{3} \mathrm{H}-5-\mathrm{HT}$. The longitudinal muscle with adherent myenteric plexus was dissected from 32 adult male rabbit ( 1 to $4 \mathrm{~kg}$ ) small intestines and homogenized in $50 \mathrm{~mm}$ Tris- $\mathrm{HCl}$ buffer at $\mathrm{pH} 7.4$. Membranes were prepared by differential centrifugation as described previously (Branchek ct al., 1984). Samples containing these membranes (200 $\mu \mathrm{g}$ of protein $/ \mathrm{m} l$ ) were incubated with ${ }^{3} \mathrm{H}-5-\mathrm{HT}$ ( 26.3 to $29.1 \mathrm{Ci} / \mathrm{mmol}$; New England Nuclear) for 10

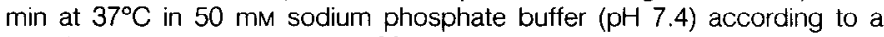
modification (Branchek et al., 1984) of the method of Bennett and Snyder (1976). Following incubation, membranes were collected by rapid filtration on Whatman GF/B filters. Radioactivity was counted in a Tracor 6895 liquid scintillation counter. Specific binding was defined as that displaced by a 1000 -fold excess of nonradioactive $5-\mathrm{HT}$ and was approximately $70 \%$ of total binding.

Radioautographic localization of ${ }^{3} \mathrm{H}-5-\mathrm{HT}$ binding and its displacement by dipeptides was done on frozen sections of guinea pig small intestine incubated for $30 \mathrm{~min}$ at $25^{\circ} \mathrm{C}$ as described previously (Branchek et al., 1984) in the presence or absence of nonradioactive 5-HT or a potential antagonist. Sections were then washed and air dried before exposure to tritium-sensitive film (B Ultrofilm, LKB Instruments, Gaithersburg, MD) for 1 to 2 weeks at $25^{\circ} \mathrm{C}$.

Dissection of the myenteric plexus for electrophysiological study. Fiftyone adult male guinea pigs ( 300 to $700 \mathrm{gm}$ ) were stunned by a blow to the head and exsanguinated. Segments of jejunum, $10 \mathrm{~cm}$ in length, beginning $2 \mathrm{~cm}$ caudal to the ligament of Treitz, were removed, washed through the lumen with Krebs solution, cut open along the mesenteric border, and trimmed. The resulting rectangular sheet $(1.5$ to $2 \mathrm{~cm}$ in width and $5 \mathrm{~cm}$ in length) of gut was pinned out flat, mucosal surface up, in a dish that was lined with a silicone elastomer (Sylgard 184, Dow Corning, Midland, MI) and had iced Krebs solution recirculating through it. The mucosal and submucosal layers of the bowel were gently removed with forceps under microscopic observation. The circular layer of smooth muscle was then gradually teased away in order to expose the myenteric plexus which remained adherent to the underlying longitudinal muscle. The resulting preparation was about 1.5 $\mathrm{cm}$ wide, $2 \mathrm{~cm}$ long, and about 50 to $60 \mu \mathrm{m}$ thick and, when stretched flat, provided excellent visualization of ganglion cells.

Electrophysiological recordings and drug application. For intracellular 
recording the longitudinal muscle with attached myenteric plexus was main tained in a low volume chamber $(2.5 \mathrm{ml})$ which was perfused at high speed (11 to $16 \mathrm{ml} / \mathrm{min}$ ) with Krebs solution (Wood and Mayer, 1979a) gassed with $95 \% \mathrm{O}_{2} / 5 \% \mathrm{CO}_{2}$ at $37^{\circ} \mathrm{C}$. This high speed perfusion is needed to prevent desensitization of neurons to $5-\mathrm{HT}$. Individual ganglia were visualized using reflected light and differential interference contrast microscopy. A ganglion to be recorded from was immobilized by pressing two L-shaped wires, called pressure feet, onto the smooth muscle on either side of the ganglion. Glass micropipettes used for recording were filled with $3 \mathrm{M} \mathrm{KCl}$ and had resistances of 40 to 80 megohms. The high impedance preamplifier (Model M707, W-P Instruments, New Haven, CT) used for recording membrane and action potentials contained negative-capacity compensation and bridge circuitry for injecting electrical current ( $<0.5 \mathrm{nA} ; 200$ to $300 \mathrm{msec}$ ) through the recording electrode. Ganglionic inputs were activated by electrical shocks (200 to 250 $\mu$ sec duration, 0.2 to $20 \mathrm{~Hz}$ frequency) applied to the fiber tracts in interganglionic connectives with monopolar extracellular electrodes made from Teflon-insulated Pt wire (25 $\mu \mathrm{m}$ in diameter). All results were recorded initially on magnetic tape and analyzed at a later time.

Drugs were applied by superfusion and/or pressure microejection. When superfusion was used, normal Krebs solution was replaced by Krebs solution containing drugs, but otherwise conditions remained the same. When superfusing solutions were changed, 10 to $140 \mathrm{sec}$ elapsed before the drug arrived in the organ bath where the tissue was maintained. Solutions containing drugs were never recirculated. When pressure microejection was used, all drugs - 5-HT (1 mM), ACh (10 mM), substance P (0.6 mM), 5-HTP-DP (1 to $10 \mathrm{~mm}$ ), and $N$-hex-5-HTP-DP (1 to $10 \mathrm{~mm}$ )-were applied to the neurons from fine pipettes ( 10 to $20 \mu \mathrm{m}$ in diameter) by pressure with pulses of nitrogen gas $\left(300 \mathrm{~kg} / \mathrm{cm}^{2} ; 10\right.$ to $999 \mathrm{msec}$ in duration) (Picospritzer II, General Valve Corp., Fairfield, NJ). Pipettes contained $0.01 \%$ fast green dye in Krebs solution as well as the compounds under study. The distance between the tip of the micropipette and the recording electrode was maintained between 50 and $100 \mu \mathrm{m}$, and the arrival of compounds at the impaled cells was visually certified. After the first application of drugs by pressure microejection, the perfusate was never recirculated

Drugs used. Acetylcholine chloride and 5-hydroxytryptamine creatinine sulfate $(5-\mathrm{HT})$ were obtained from Sigma Chemical Co. (St. Louis, MO). NAcetyl-5-hydroxytryptophyl-5-hydroxytryptophan amide (5-HTP-DP) was graciously supplied by Drs. M. Wilchek and S. A. Khan. N-Hexanoyl-5-hydroxytryptophyl-5-hydroxytryptophan amide $N$-hex-5-HTP-DP was from M. Wilchek. 5-Methoxytryptamine hydrochloride (5-MEOT) was from Sigma Chemical Co. substance $P$ was from Peninsula Laboratories (Belmont, CA), and tetrodotoxin was from Sankyo (Tokyo, Japan).

Drug preparation. All drugs except for substance $\mathrm{P}$ and 5-HTP-DP and $N$ hex 5-HTP-DP used in the present study wore dissolved with Krobs solution. Substance $P$ was dissolved with $0.1 \%$ bovine serum albumin and Krebs solution and stored at $-20^{\circ} \mathrm{C}$ until used. When used, substance $P$ was diluled 10 tirnes wilh Krebs solulion. 5-HTP-DP and N-hex-5-HTP-DP were first dissolved with $100 \%$ ethanol or dimethylsulfoxide (DMSO) and then diluted with Krebs solution to a final concentration of $10 \%$ ethanol or $10 \%$ DMSO. Solutions containing 5-HTP-DP (1 to $10 \mathrm{~mm}$ ) were stored in the dark at $-20^{\circ} \mathrm{C}$. As controls, the effects of 0.1 to $10 \%$ ethanol and DMSO and 0.01 to $0.1 \%$ fast green solution on the electrophysiological behavior of 14 type II/AH and 4 NS myenteric neurons were examined. No actions of ethanol, DMSO, or fast green were found.

\section{Results}

Effects of 5-HTP-DP and N-hex-5-HTP-DP on the binding of ${ }^{3} \mathrm{H}-5-H T$

Both 5-HTP-DP and N-hex-5-HTP-DP antagonized the binding of ${ }^{3} \mathrm{H}-5-\mathrm{HT}$ to isolated enteric membranes. When tested against $10 \mathrm{nM}$ ${ }^{3} \mathrm{H}-5-\mathrm{HT}$, the $\mathrm{IC}_{50}$ for inhibition of ${ }^{3} \mathrm{H}-5-\mathrm{HT}$ binding was $1.2 \pm 0.6 \mu \mathrm{M}$ $(n=8)$ for 5-HTP-DP and $5.6 \pm 5.0 \mu \mathrm{M}(n=4)$ for $N$-hex-5-HTP-DP. $K_{1}$ values were approximately $0.25 \mu \mathrm{M}$ for 5 -HTP-DP and $1.19 \mu \mathrm{M}$ for $N$-hex-5-HTP-DP. These compounds were not as potent as $5-\mathrm{HT}$ in antagonizing the binding of ${ }^{3} \mathrm{H}-5-\mathrm{HT}$. The $\mathrm{IC}_{50}$ for $5-\mathrm{HT}$ is $46 \mathrm{nM}$ (Branchek et al., 1984); thus 5-HTP-DP is about 30 times less potent and $N$-hex-5-HTP-DP is about 90 times less potent than 5 -HT itself. In contrast to the ability of the dipeptides to antagonize binding of ${ }^{3} \mathrm{H}-5-\mathrm{HT}, 5-\mathrm{MEOT}$ (up to $10 \mu \mathrm{M}$ ), as noted previously (Branchek et al., 1984), produced no inhibition of ${ }^{3} \mathrm{H}-5-\mathrm{HT}$ binding at all. Both 5 HTP-DP and N-hex-5-HTP-DP were found by radioautography to interfere with the binding of ${ }^{3} \mathrm{H}-5-\mathrm{HT}$ to all sites of the guinea pig small intestine (Fig. 2) as well as to membranes derived from rabbit gut. As expected, 5-MEOT (up to $10 \mu \mathrm{M}$ ) does not block the radioautographically assayed binding of ${ }^{3} \mathrm{H}-5-\mathrm{HT}$ in the guinea pig gut

\section{Physiological studies}

Classification of myenteric neurons. The neurons of the myenteric plexus were classified physiologically into three categories (Holman et al., 1972; Nishi and North, 1973; Hirst et al., 1974; Wood, 1983). Type $\mathrm{I} / \mathrm{S}$ cells were defined as those with a high input resistance, which spiked repeatedly during the injection of a depolarizing current and which displayed anodal break excitation. Type I/AH cells were defined as those with a low input resistance and which displayed a characteristic prolonged afterhyperpolarization following an action potential. During the afterhyperpolarization the cell was refractory. These cells usually did not show anodal break excitation except when activated by application of exogenous compounds such as 5 HT or during a slow EPSP. NS cells were defined as those cells that did not spike in response to injection of depolarizing current, stimulation of interganglionic fiber tracts, or application of drugs. The sample studied included 52 type II/AH cells, 32 NS cells, and 10 type $1 / \mathrm{S}$ cells.

The action of 5-HT on myenteric neurons. In confirmation of previous observations by Wood and Mayer (1979b) and Johnson et a!. (1980b), 5-HT applied by pressure microejection or by superfusion (at high concentration: 10 to $100 \mu \mathrm{M}$ ) was found to induce a long lasting depolarization in type $1 \mathrm{I} / \mathrm{AH}$ neurons. After microejection of an approximately threshold pulse of $5-\mathrm{HT}$, the mean duration of the response was $29.0 \pm 2.6 \mathrm{sec}$ and the amplitude was $14.5 \pm 1.4$ $\mathrm{mV}(\mathrm{N}=16)$. This response was associated with an increased input resistance. During the response, the afterhyperpolarization that characterizes type II/AH neurons was antagonized and, as a consequence, the cells became hyperexcitable. This effect of $5-\mathrm{HT}$ is concentration dependent (Fig. 3) and was seen in 61\% of type II/ AH cells (Table I). Other types of effect were also seen in response to application of 5-HT by microejection. The most common effect besides the slow depolarization was a rapid depolarization associated with a fall in input resistance (Fig. 4) which was observed in $55 \%$ of type II/AH cells. After microejection of an approximately threshold pulse of $5 \cdot \mathrm{HT}$, the mean duration of this response was 2.1 $\pm 0.1 \mathrm{sec}$ and the amplitude was $19.6 \pm 2.3 \mathrm{mV}(N=14)$. This response is thus significantly shorter than that of the slow depolarization evoked by 5 -HT $(p<0.001)$. The fast response to 5 -HT was not antagonized by hexamethonium $(0.1 \mathrm{mM})$, tetrodotoxin $(3.1 \mu \mathrm{M})$, $\mathrm{Ca}^{2+}$-free media (with $0.1 \mathrm{mM}$ EGTA), high $\mathrm{Mg}^{2+}(12.5 \mathrm{~mm}$ )-containing media, or naloxone $(10 \mu \mathrm{M})$. It was always abolished by desensitization with superfused $5-\mathrm{HT}(10 \mu \mathrm{M})$. The fast response, therefore, appears to be a direct postsynaptic response to $5-\mathrm{HT}$. More rarely (5\%), a hyperpolarization, also associated with a decrease in input resistance, was seen. The fast depolarization was usually accompanied by a burst of action potentials which in turn were followed by an afterhyperpolarization. This biphasic response has been described by Johnson et al. (1980b). The biphasic response was often, in turn, succeeded by the characteristic 5-HT-induced slow depolarization during which the afterhyperpolarization of type II/AH cells was blocked and the input resistance was increased (Figs. 4, 7, and 8). This complex fast and slow response to 5 -HT was seen in $29 \%$ of type II/AH cells (Table I). Type I/S cells and NS cells also responded to $5-\mathrm{HT}$. The responses of these cells to $5-\mathrm{HT}$ were studied much less thoroughly than those of type I/AH cells which formed the major target of this investigation; however, the types of response seen and their incidence in the cells encountered are summarized in table l.

\section{Actions of 5-MEOT on type I//AH neurons}

5-MEOT, applied to the surface of three type I/AH neurons and one type $\mathrm{I} / \mathrm{S}$ neuron by pressure microejection, failed to mimic any of the actions of 5-HT applied to the same neurons, even when 

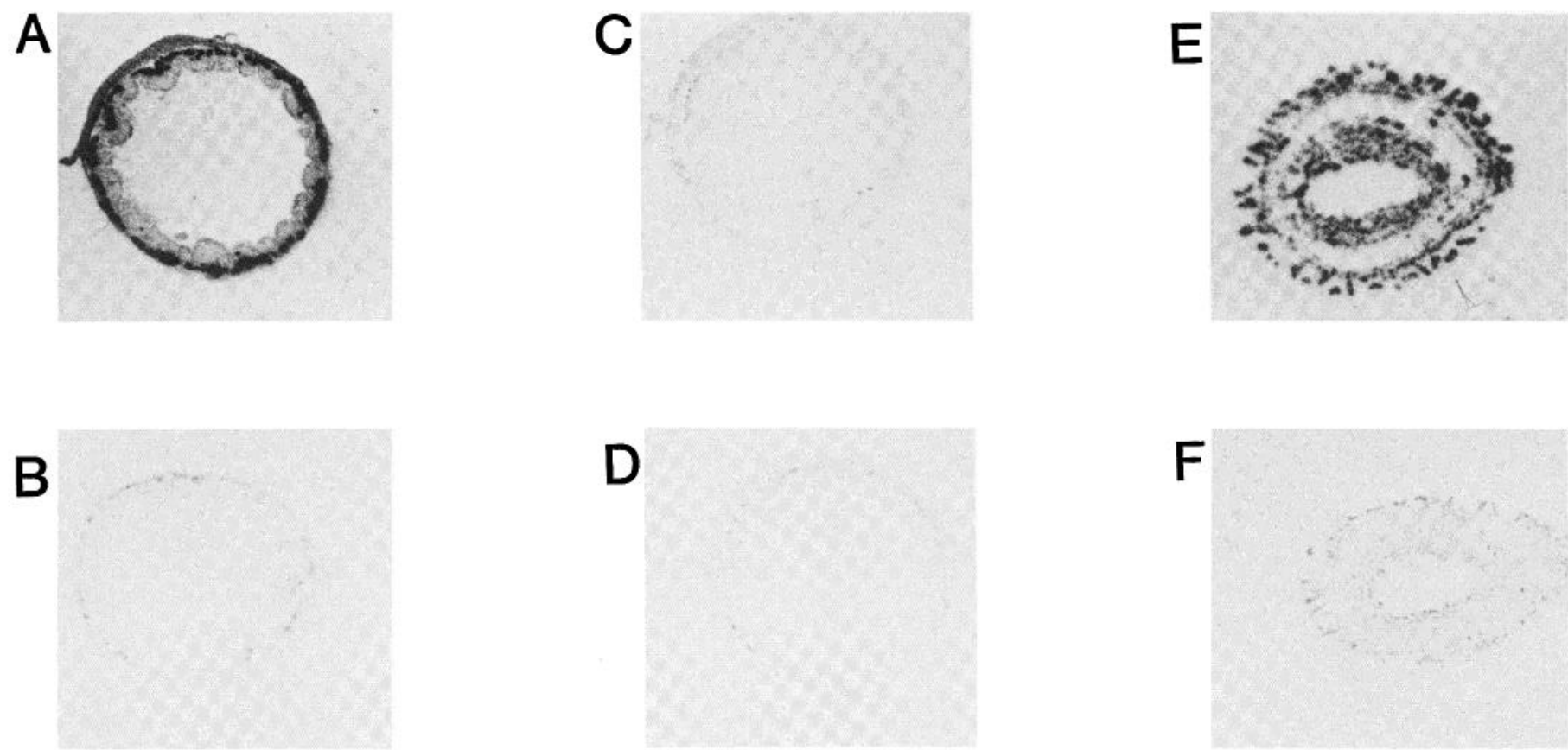

F

Figure 2. Radioautographs showing the binding of ${ }^{3} \mathrm{H}-5-\mathrm{HT}$ to fresh frozen sections of guinea pig small intestine. All sections were incubated with ${ }^{3} \mathrm{H}-5$ $\mathrm{HT}(10 \mathrm{nM})$ in the presence or absence of $5-\mathrm{HT}(10 \mu \mathrm{M})$ or potential antagonists $(10 \mu \mathrm{M})$, and binding was assessed using ${ }^{3} \mathrm{H}$-sensitive film. $A$ to $D$ are nearserial sections from one gut and $E$ and $F$ are from another. $A,{ }^{3} \mathrm{H}-5-\mathrm{HT}$ alone; $B,{ }^{3} \mathrm{H}-5-\mathrm{HT}$ plus $5-\mathrm{HT}$ (control for sections exposed to dipeptides); $C$, ${ }^{3} \mathrm{H}-5$ - $\mathrm{HT}$ plus 5-HTP-DP; $D,{ }^{3} \mathrm{H}$-5-HT plus $N$-hex-5-HTP-DP; $E,{ }^{3} \mathrm{H}-5$-HT plus 5-MEOT; $F,{ }^{3} \mathrm{H}-5$-HT plus 5 -HT (control for 5-MEOT section).

Figure 3. Concentration dependence of the action of 5-HT. Membrane potential of a type II/AH neuron is illustrated. Increasing the duration of the pulse used for pressure microejection of $5-\mathrm{HT}$ (1 $\mathrm{mm}$; arrowheads) from 50 to $300 \mathrm{msec}$ increases the amplitude of the depolarization, its duration, and the frequency of action potentials induced by $5-\mathrm{HT}$. Constant hyperpolarizing current pulses were injected into the cell through the recording microelectrode. Note the increase in input resistance during the depolarizing re sponse to 5-HT. This effect was not blocked by tetrodotoxin $(3.1 \mu \mathrm{M}$; not shown). The resting membrane potential was $-71 \mathrm{mV}$.

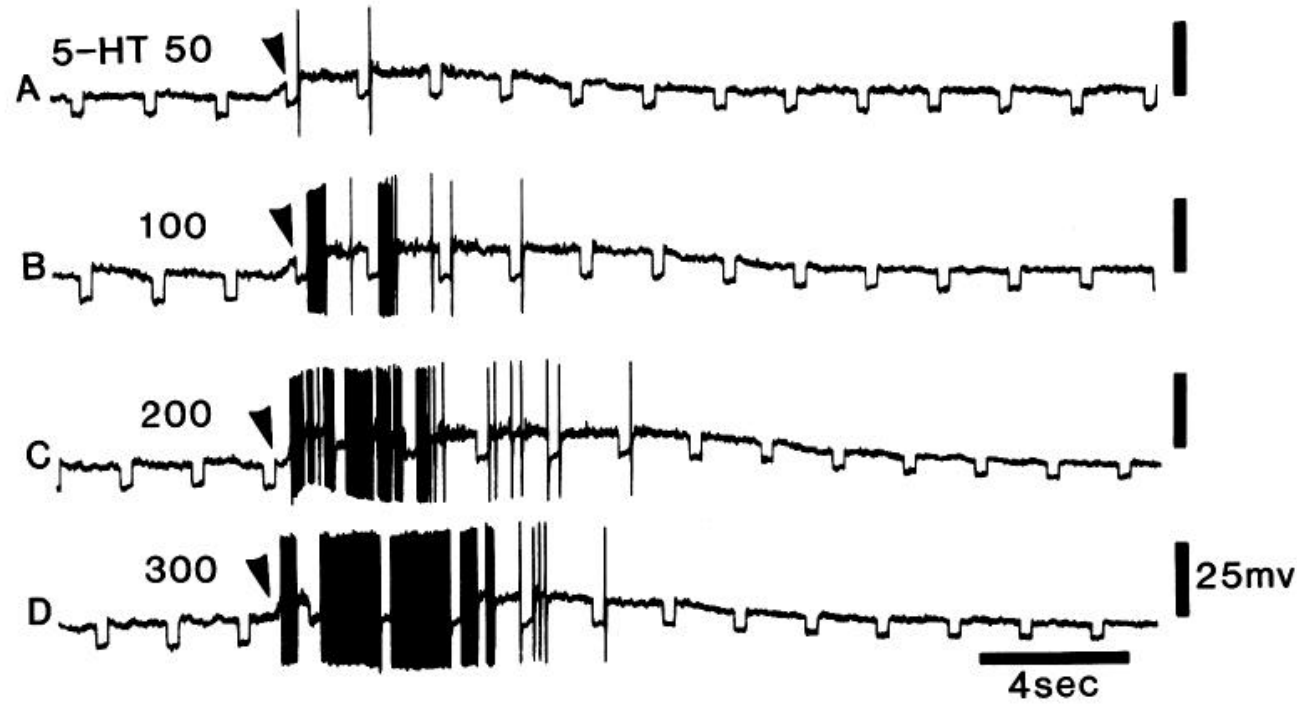

applied at 20 times the volume of 5-HT (Fig. 4). When 5-HT was applied after 5-MEOT, its action was unchanged from control (Fig. $4, C$ to $E$ ). In three of nine type I/AH cells, 5-MEOT applied by superfusion at high concentration (5 to $10 \mu \mathrm{M}$ ) did produce a depolarization. In five of nine type II/AH cells and one of one type I/ $\mathrm{S}$ cell, 5-MEOT superfusion (10 $\mu \mathrm{M})$ had no effect. One type I/AH cell was hyperpolarized by 5-MEOT. However, the depolarizing effect of 5-MEOT (not illustrated) was quite different from that of 5-HT. It was a prolonged action associated with a fall, not a rise, in input resistance. When cells were depolarized by 5-MEOT, they no longer responded to $5-\mathrm{HT}$. Although $5-\mathrm{HT}$ can also induce a depolarization associated with a decrease in input resistance (fast depolarization; see above) this $5-\mathrm{HT}$ effect is transient. It is evoked only by pulses of 5-HT and cannot be induced by superfusion; therefore, the actions of 5-MEOT and 5-HT differed in means of elicitation and time course. Moreover, the fast depolarizing response to $5-\mathrm{HT}$ could be elicited in cells that did not respond to superfusion with 5-MEOT (Fig. 5) Furthermore, the fast response to $5-\mathrm{HT}$ in these cells was not blocked by superfusion with 5-MEOT. In contrast, the fast depolarization induced by $5-\mathrm{HT}$, like the slow depolarization, was readily antagonized by desensitizing the preparations by superfusion with 5-HT $(10 \mu \mathrm{M}$ ) itself (Fig. 5). It seems, therefore, that 5-MEOT does not act on the same enteric neural receptors as does $5-\mathrm{HT}$.

\section{Antagonism of the actions of 5-HT on type II/AH cells by 5-HTP-DP}

Superfusion of tissues with 1 to $10 \mu \mathrm{M}$ 5-HTP-DP reversibly antagonized the slow depolarization associated with increased input resistance induced by 5-HT (Fig. 6). This action of 5-HTP-DP could be overcome by increasing the duration of the pressure pulse for microejection of 5-HT (and thus the amount of 5-HT applied). Antagonism of the action of 5-HT could also be demonstrated by 
TABLE ।

Neural responses to 5-HT

\begin{tabular}{|c|c|c|c|c|}
\hline \multirow{2}{*}{ Types of Response to 5-HT } & \multicolumn{3}{|c|}{$\begin{array}{c}\text { Type of Myenteric } \\
\text { Neuron }\end{array}$} & \multirow{2}{*}{ Total } \\
\hline & $1 / S$ & $\| / \mathrm{AH}$ & NS & \\
\hline $\begin{array}{l}\text { Slow depolarization only (input } \\
\text { resistance increased) }\end{array}$ & 2 & 12 & 1 & 15 \\
\hline $\begin{array}{l}\text { Fast depolarization and slow } \\
\text { depolarization }\end{array}$ & 0 & 11 & 0 & 11 \\
\hline $\begin{array}{l}\text { Fast depolarization only (input } \\
\text { resistance decreased) }\end{array}$ & 1 & 10 & 4 & 15 \\
\hline Hyperpolarization & 3 & 2 & 1 & 6 \\
\hline No response & $\underline{1}$ & $\underline{3}$ & $\underline{22}$ & $\underline{26}$ \\
\hline Total & $\overline{7}$ & $\overline{38}$ & $\overline{28}$ & $\overline{73}$ \\
\hline
\end{tabular}

close pressure microejection of 5-HTP-DP (Fig. 7). In $40 \%$ of cells both the fast and the slow depolarization induced by $5-\mathrm{HT}$ were blocked by 5-HTP-DP; however, the ability of the dipeptide to block the fast depolarization was not constant (Fig. 8). In contrast, the slow depolarization was more sensitive to antagonism by 5-HTP-DP and could be blocked by the dipeptide at concentrations of drug that did not block the fast depolarization (Fig. 8). The slow depolarization induced by 5-HT was reversibly antagonized by 5-HTP-DP in $100 \%$ of trials. This antagonistic action of 5-HTP-DP against 5-HT was concentration dependent and required relatively high concentrations of drug. In superfusion experiments at least $1 \mu \mathrm{M}$ 5-HTP-DP was required and, for some cells, a concentration of $10 \mu \mathrm{M} 5$-HTP$\mathrm{DP}$ (and rarely $20 \mu \mathrm{M}$ ) was needed to block the action of microejected $5-\mathrm{HT}$. When both compounds were given by pressure microejection, concentrations of the two compounds at the impaled cell were not known; however, 10 to 30 drops of 5-HTP-DP $(10 \mathrm{~mm})$ were required to antagonize the effects of 1 drop of $5-\mathrm{HT}(1 \mathrm{~mm})$ (Fig. 8). Twenty drops of 5-HTP-DP reduced the mean depolarization induced by $5-H T$ to $33 \%$ of the control value $(p<0.01)$ and the duration to $47 \%(p<0.01)$. Thirty drops virtually abolished the response to $5-\mathrm{HT}$, reducing the mean depolarization to $<10 \%$ of control and the duration to $<15 \%(p<0.01)$.

5-HTP-DP (10 mM) applied by microejection to the surface of type II/AH neurons failed to mimic any of the agonist actions of 5-HT (1 $\mathrm{mm}$ ) applied to the same cells. No cells displayed either a fast or a slow depolarization, a hyperpolarization, or a change in input resistance in response to microejection of 1 to 30 drops of 5-HTP-DP (10 $\mathrm{mM})$. The drug thus appears only to be a $5-\mathrm{HT}$ antagonist. $N$-hex-5HTP-DP had actions similar to those of 5-HTP-DP except that it was less potent against exogenous 5-HT and, perhaps because of its greater lipid solubility, was difficult to wash out.

\section{Specificity of 5-HTP-DP as a 5-HT antagonist}

In order to examine the specificity of 5-HTP-DP for 5-HT receptors, the ability of 5-HTP-DP to antagonize responses of type $\| / A H$ neurons to substance $P$ and $A C h$ was investigated. The action of substance $P$ (Katayama and North, 1978; Katayama et al., 1979) and the muscarinic actions of ACh (Morita et al., 1982; North and Tokimasa, 1982) on these cells are similar to the slow depolarization induced by $5-\mathrm{HT}$. Both substance $P$ and $\mathrm{ACh}$, as well as $5-\mathrm{HT}$, produce a long-lasting depolarization of myenteric neurons associated with an increase in input resistance. Neither the response of type II/AH neurons to substance $P$ (Fig. 9) nor the muscarinic response of these neurons to $A C h$ were blocked by superfusion with as much as 10 to $20 \mu \mathrm{M} 5$-HTP-DP. In addition, the response elicited by pressure microejection of 1 drop of ACh was not blocked by pressure microejection of 30 drops of 5-HTP-DP ( 1 to $10 \mathrm{~mm}$ ) (Fig. 10). Nevertheless, this amount of pressure microejected 5-HTPDP readily antagonizes responses to 1 drop of $5-\mathrm{HT}$ (see Figs. 7 and 8 ).

As a further test of the specificity of 5-HTP-DP, the action of the compound on fast EPSPs was determined. These were examined in type $\mathrm{I} / \mathrm{S}$ cells and were elicited by stimulation of an interganglionic fiber tract. This response is known to be nicotinic (Nishi and North, 1973) and, indeed, we found the response to be abolished by hexamethonium (0.1 mM) (Fig. 11). Testing 5-HTP-DP against the fast EPSP, therefore, evaluates the action of the compound on nicotinic receptors and also on the release of $A C h$. Superfusion with 5-HTP-DP $(1.0$ to $10 \mu \mathrm{M})$ did not antagonize the fast EPSP induced by fiber tract stimulation (Fig. 12); therefore, 5-HTP-DP does not antagonize the nicotinic actions or the release of $A C h$. In contrast to 5-HTP-DP, 5-HT is known to act presynaptically to reduce the release of ACh and thus diminish the amplitude of the fast EPSP (North et al., 1980). This presynaptic effect of 5-HT, like its postsynaptic actions, was reversibly antagonized by 5-HTP-DP (Fig. 12).

\section{Effect of 5-HTP-DP on slow EPSPS in type I/AH neurons}

Slow EPSPS can be elicited in both type I/S and type I/AH neurons (Johnson et al., 1980a); however, 5-HT has only been postulated to be a mediator of slow EPSPs in type II/AH cells (Wood and Mayer, 1979b). The slow EPSP elicited in type II/AH neurons by repetitive fiber tract stimulation is mimicked by the slow depolarization induced by 5-HT (Fig. 13). The action of 5-HTP-DP was thus tested on slow EPSPs elicited by repetitive stimulation of fiber tracts in interganglionic connectives. The slow EPSP in type II/AH neurons was found

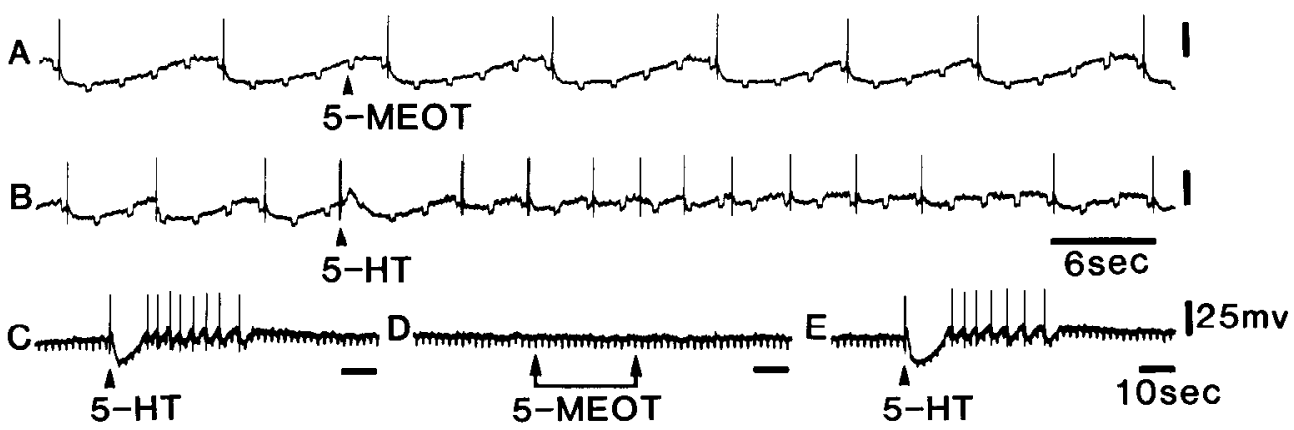

Figure 4. Effects of 5-MEOT and 5-HT on a type I/AH neuron. The cell is injected with constant hyperpolarizing current pulses. Action potentials are followed by a pronounced afterhyperpolarization (AH). A, 5-MEOT (1 mM; arrowhead) applied by pressure microejection has no effect. B, Application of 5 HT (1 mM, $800 \mathrm{msec}$; arrowhead) by pressure microejection causes several action potentials and a fast (transient) depolarization associated with decreased input resistance followed by a slow depolarization. During the slow depolarization input resistance is increased, the AH is antagonized, and action potential frequency increases. C. At a slower speed $5 \mathrm{HT}(1 \mathrm{~mm}, 800 \mathrm{msec}$; arrowhead) induces a similar response. During the initial fast depolarization evoked by 5-HT the cell fires several action potentials. These are followed by a pronounced AH which is lost during the following phase of slow depolarization. The cell is hyperexcitable during this late portion of the response to 5 -HT. D. After this response to 5-HT, 5-MEOT ( $1 \mathrm{mM}, 800 \mathrm{msec}$; 20 drops between arrows) produces no effect. $E$, Following application of 5-MEOT the application of 5-HT evokes an effect similar to that seen before 5-MEOT. The resting membrane potential was $-74 \mathrm{mV}$. 


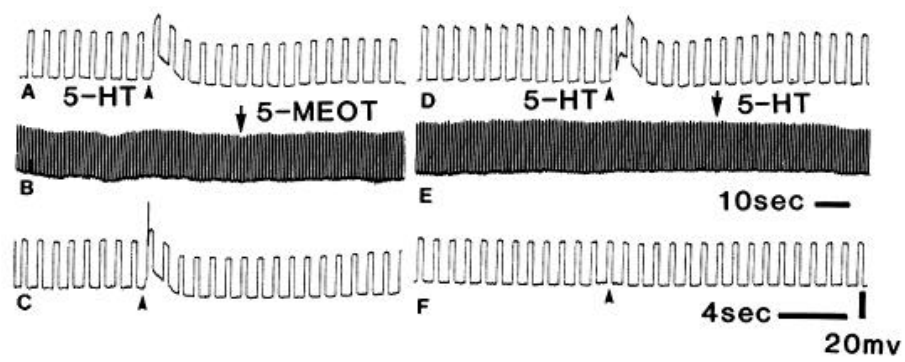

Figure 5. The fast depolarization evoked by $5-\mathrm{HT}$ and the effects of 5 MEOT. Constant depolarizing current pulses were injected through the recording micropipette into a type $I / \mathrm{AH}$ neuron. $A$, The ejection (arrowhead) of 5.HT (1 mM, $999 \mathrm{msec})$ induces a fast depolarization. B, Superfusion with 5-MEOT $(10 \mu \mathrm{M})$ begins at the arrow and by itself did not cause any change in membrane potential or input resistance. $C$, When $5-\mathrm{HT}$ is microejected (arrowhead), a fast depolarization is evoked despite the continued superfusion with 5-MEOT. D, 5-MEOT is washed out and the preparation (arrowhead) continues to respond to $5-\mathrm{HT}$ as before. $E$, Superfusion with $5-\mathrm{HT}(10 \mu \mathrm{M})$ is begun at the arrow. F, Superfusion with 5-HT has desensitized the preparation and 5-HT no longer evokes a response. The resting membrane potential of this cell was $-74 \mathrm{mV}$.

to be reversibly antagonized by 5 -HTP-DP or $N$-hex-5-HTP-DP in eight of eight type II/AH cells (Figs. 14 and 15). Both blocked the slow EPSP when applied by superfusion at 1 to $10 \mu \mathrm{M}$ or when applied by pressure microejection from pipettes containing $10 \mathrm{~mm}$ (Fig. 14) but not $1 \mathrm{~mm}$ concentrations of the peptides. The slow EPSP was also blocked in these neurons by desensitization to 5-HT (Fig. 15). Repetitive stimulation of a fiber tract sometimes evoked a hyperpolarizing response associated with a decrease in input resistance prior to the appearance of the slow EPSP (Fig. 15). This effect was blocked neither by $N$-hex-5-HTP-DP nor by desensitization to 5 HT. Similarly, antidromic action potentials were often elicited in type IIAH neurons by fiber tract stimulation (not illustrated). These potentials were never affected by superfusion with 5-HTP-DP $(10 \mu \mathrm{M})$.

\section{Discussion}

Three major objectives formed the core of the current study. One was to evaluate the ability of 5-MEOT to act as an agonist or antagonist at 5-HT receptors. Previous experiments on the binding of ${ }^{3} \mathrm{H}-5-\mathrm{HT}$ (Branchek et al., 1984; Gershon et al., 1984a, b) had led to the prediction that 5-MEOT would not act like 5-HT. A second objective was to analyze the action of two dipeptides of 5-hydroxytrptophan, 5-HTP-DP and $N$-hex-5-HTP-DP, on the high affinity enteric binding of ${ }^{3} \mathrm{H}-5-\mathrm{HT}$ and on neurons of the myenteric plexus. Studies of the structural requirements for affinity at enteric ${ }^{3} \mathrm{H}-5-\mathrm{HT}$ binding sites (Branchek et al., 1984; Gershon et al., 1984b) and the known pharmacology of 5-HT M receptors (Drakontides and Gershon, 1968; Fozard and Mobarok Ali, 1978; Costa and Furness, 1979b) had led to the prediction that these compounds would be active at $M$ receptors. A final objective was to use these compounds, if they could be shown to be specific 5-HT M receptor antagonists, in order to test the hypothesis of Wood and Mayer (1979b) that 5-HT is a mediator of slow EPSPs in type $\| / A H$ neurons of the myenteric plexus. The experimental plan, therefore, was designed (1) to provide a further test of the proposal that the high affinity ${ }^{3} \mathrm{H}-5-\mathrm{HT}$ binding sites in the gut are M 5-HT receptors and (2) to gain additional insight into the physiological role of 5-HT as a neurotransmitter in the ENS.

5-MEOT produced no effect on membrane potential when applied to the surface of myenteric neurons by pressure microejection. It neither mimicked nor antagonized the action of 5-HT. A minority of cells were depolarized when 5-MEOT was superfused over the tissue in high concentration. This action of superfused 5-MEOT, however, was quite different from the actions of $5-\mathrm{HT}$. It differed from the prolonged slow effect of 5-HT (which could be elicited either by microejection or by superfusion) because the 5-MEOT-induced depolarization was accompanied by a fall in input resistance, whereas the slow depolarization induced by $5-\mathrm{HT}$ was accompanied by a rise. Moreover, 5-HT never produced a decline in input resistance when applied by superfusion. In addition, the postsynaptic depolarization that 5-HT induces when applied by microejection that is associated with a fall in input resistance, in contrast to the action of superfused 5-MEOT, is a fast, rapidly accommodating, response. Finally, desensitization of preparations to $5-\mathrm{HT}$ blocks this fast response to $5-\mathrm{HT}$, but superfusion with high concentrations of 5 MEOT does not. 5-MEOT, therefore, usually does not affect myenteric neurons which respond to 5-HT. When it does have an action on these cells, its effect is not like that of 5-HT and, thus, the action of 5-MEOT seems unlikely to be mediated by 5-HT receptors. It seems probable, therefore, that, as first concluded by Gyermek (1966), 5-MEOT is not an agonist at 5-HT M receptors. These observations, however, may provide some insight into apparent discrepancies concerning this drug that have appeared in the literature. Fozard and Mobarok Ali (1978) reported that 5-MEOT did not act on $\mathrm{M}$ receptors for $5-\mathrm{HT}$ in the heart but did cause a neurally mediated contraction of the guinea pig ileum. Since a specific 5-HT $M$ receptor antagonist was not available at the time they did their study, Fozard and Mobarok Ali (1978) concluded that 5-MEOT contracted the ileum by acting on 5-HT receptors. However, it seems possible, from the current study, that 5-MEOT may depolarize some myenteric neurons leading to the release of $\mathrm{ACh}$ and contraction of the ileum through a mechanism independent of an action on 5-HT receptors. It is thus advantageous to study the effects of compounds

Figure 6. Antagonism of the slow depolarizing response to 5 - $\mathrm{HT}$ by superfusion with 5-HTP-DP. This type ॥/AH cell was injected with constant hyperpolarizing current pulses through the recording micropipette. A, A brief 50-msec (arrow) microejection of 5-HT induces a slow depolarization. During the response there is anodal break excitation. B, The response to 5-HT (arrow) is blocked by superfusion with $10 \mu \mathrm{M} 5$-HTPDP (the response to a $100-\mathrm{msec}$ pulse of 5 HT was reduced (not shown) but not abolished by 5-HTP-DP). $C$, When the dipeptide is washed out, the slow depolarizing response to 5-HT (arrow) returns. Action potentials occur during the depolarizing response and there is also anodal break excitation. The resting membrane potential was $-71 \mathrm{mV}$.
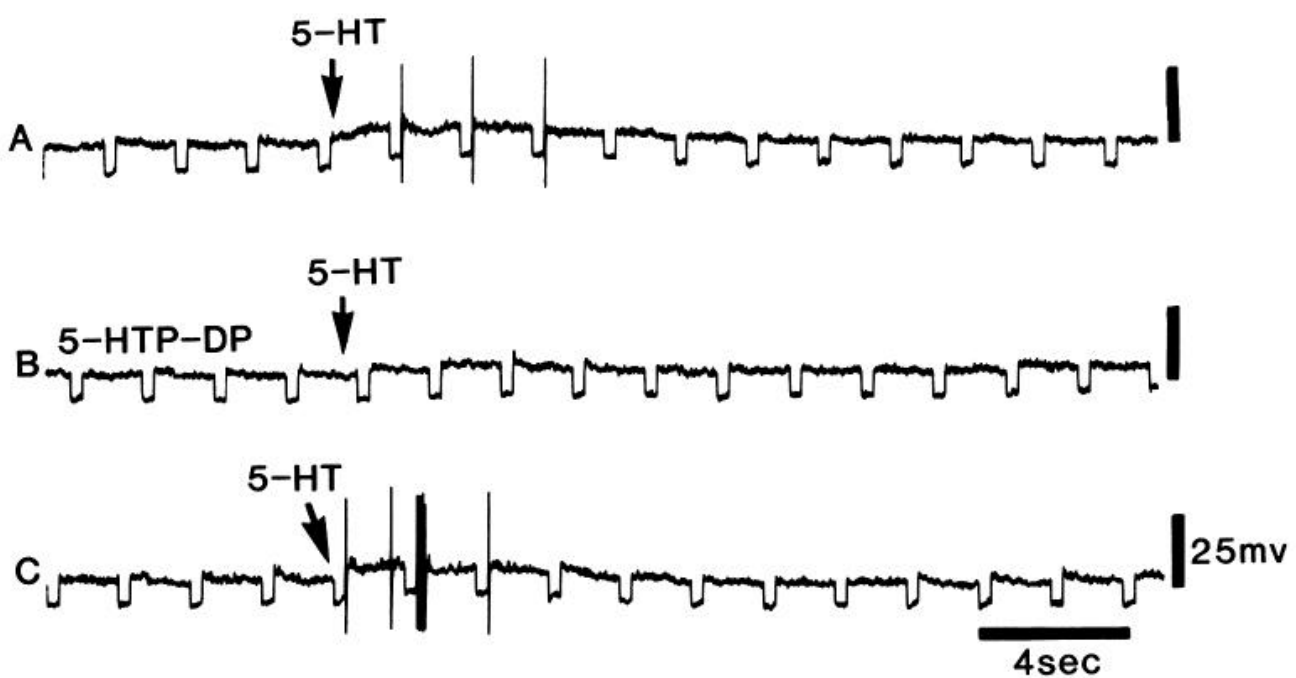


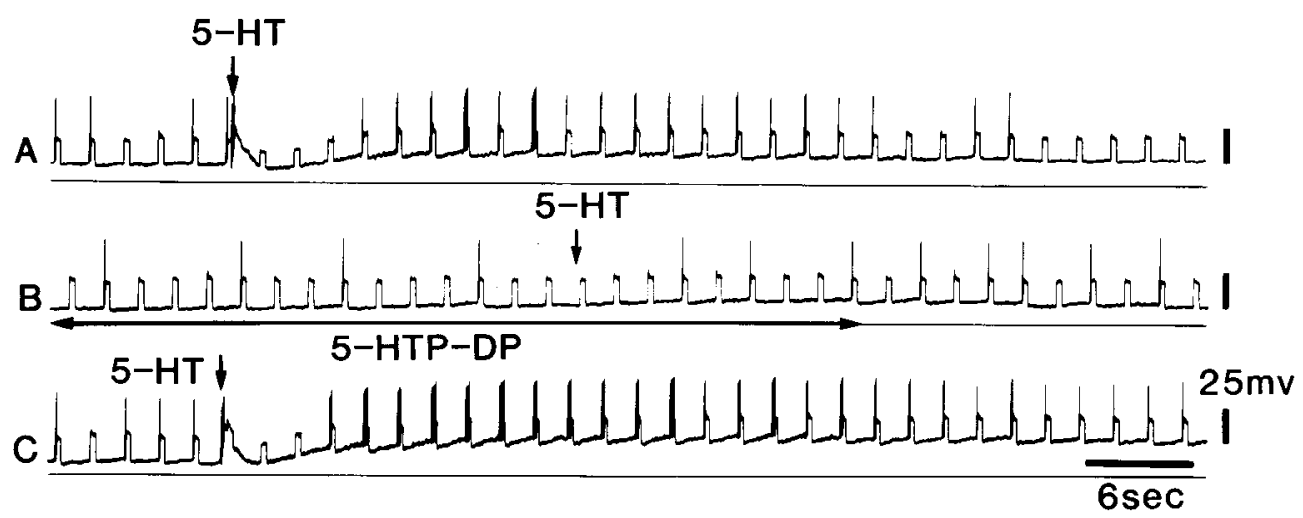

Figure 7. Antagonism of the response to 5-HT by microejection nearby of 5-HTP-DP. Constant depolarizing current pulses were injected through the recording micropipette into a type $\mathrm{I} / \mathrm{AH}$ neuron. In the absence of drugs a single action potential is evoked at the onset of the injected current pulse, but the cell does not spike repeatedly. A, Microejection of $5-\mathrm{HT}(1 \mathrm{~mm}, 999 \mathrm{msec}$; arrow) first induces a fast depolarization that is associated with a burst of action potentials. This change is followed by an afterhyperpolarization (during which input resistance is low) that, in turn, is succeeded by a slow, very longlasting depolarizing response $(12 \mathrm{mV}, 105 \mathrm{sec})$. During the depolarizing response depolarizing current injection evokes multiple action potentials. $B$, Pressure microejection of 20 drops of 5-HTP-DP (10 mM, $999 \mathrm{msec}$; horizontal arrow) blocks all phases of the response to one drop of 5-HT (arrow). C. After the dipeptide is washed out, the slow depolarizing response to 5 -HT returns $(14 \mathrm{mV}, 125 \mathrm{sec})$. The resting membrane potential was $-67 \mathrm{mV}$.

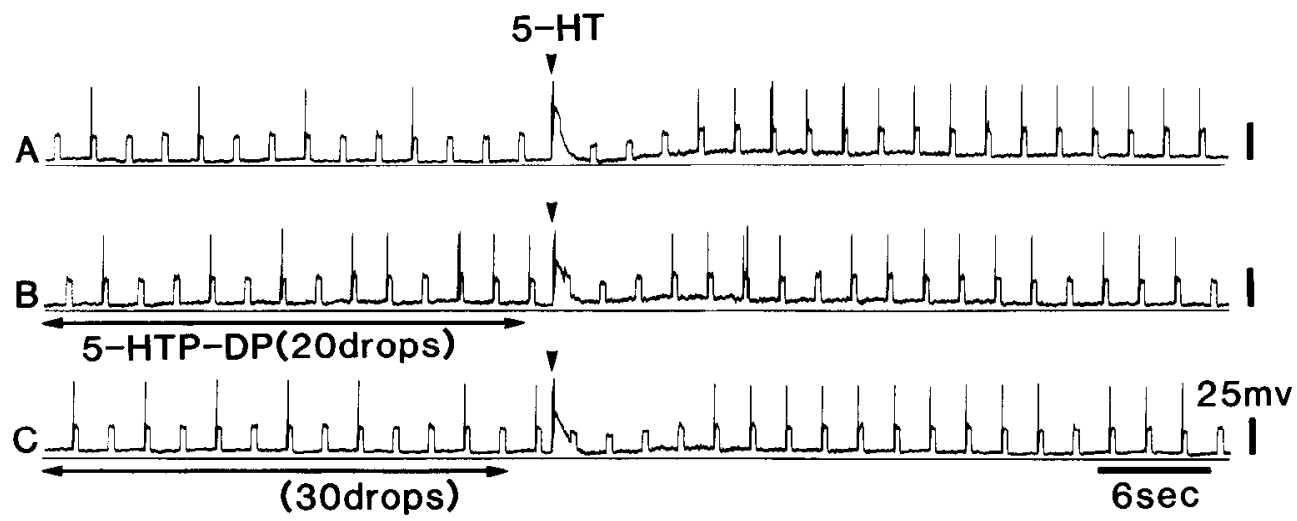

Figure 8. Concentration dependence of the antagonism of slow depolarizing responses to 5-HT by 5-HTP-DP. This type II/AH neuron was injected with constant depolarizing current pulses through the recording micropipette. A, The control response to 5-HT (1 mM, $999 \mathrm{msec}$; arrowhead) is complex; both fast and, later, slow depolarizing responses are seen. $B$, Microejection of 20 drops (10 mm, 999 msec; horizontal arrow) of 5-HTP-DP does nul antagonice the fast response to $5-\mathrm{HT}$ but does partially block the slow depolarization. $C$, Microejection of 30 drops of 5-HTP-DP still does not inhibit the fast response to $5 \cdot \mathrm{HT}$, but the later, slow response is now virtually abolished. The resting membrane potential was about $-55 \mathrm{mV}$. In this preparation the mean amplitude of the 5-HT-induced slow depolarization was $5.1 \pm 0.4 \mathrm{mV}$ and the duration was $31.9 \pm 1.8 \mathrm{sec}$. After 20 drops of $5-\mathrm{HIP}-\mathrm{DP}$, the mean amplitude was 1.7 $\pm 0.9 \mathrm{mV}$ and the duration was $15.0 \pm 7.6 \mathrm{sec}(\rho<0.01 ; 23 \mathrm{df})$. After 30 drops of 5 -HTP-DP no response was elicited by 5 -HT in two of three trials; the maximum remaining depolarization was $1.5 \mathrm{mV}$ for $15 \mathrm{sec}$ duration.

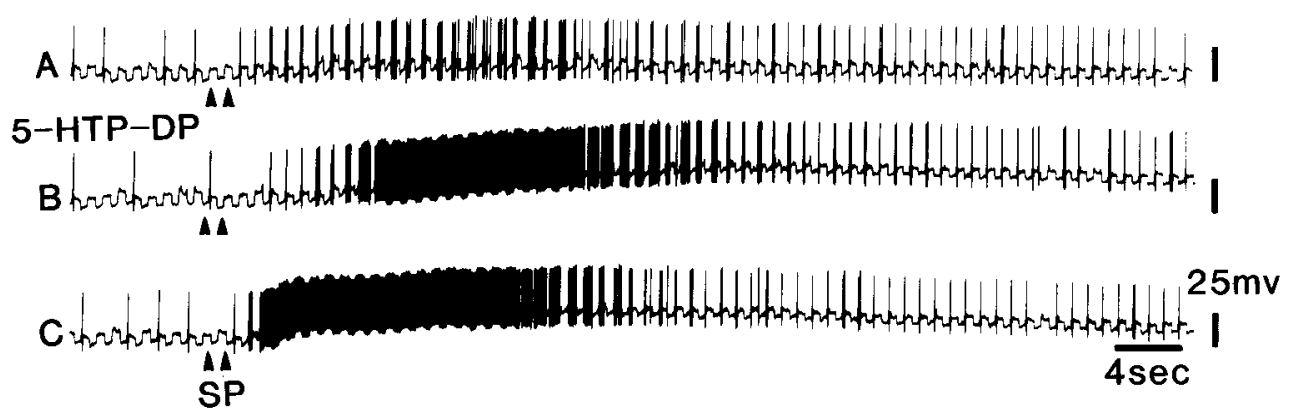

Figure 9. Effect of 5-HTP-DP on the response of a type II/AH neuron to microejection of substance $P$. The cell was injected with constant depolarizing current pulses through the recording micropipette. $A$, Substance $P(0.6 \mathrm{~mm}$ ): two pulses (each 900 msec; arrowheads) induce a slow, prolonged depolarization during which the af terhyperpolarization is reduced and the cell is hyperexcitable. $B$, Superfusion with $20 \mu \mathrm{M}$ 5-HTP-DP fails to block the resporise to substance P. C, After the dipeptide is washed out, the response to substance $P$ remains as vigorous as betore. The resting membrane potential was $-67 \mathrm{mV}$.

on myenteric neurons themselves. Indirect conclusions based on contraction of ileal smooth muscle may be misleading, and discrepancies between data obtained with whole ileum and results obtained with intracellular recordings from individual myenteric neurons may reasonably be expected. In any case, the observations made in the current investigation of the effects of 5-MEOT on individual myenteric neurons are consistent with the observation that 5-MEOT does not antagonize the high affinity enteric binding of ${ }^{3} \mathrm{H}-5-\mathrm{HT}$ and, thus, support the notion that enteric high affinity ${ }^{3} \mathrm{H}-5-\mathrm{HT}$ binding sites are 5-HT receptors.

The dipeptides of 5-hydroxytryptophan were found to be antagonists of the enteric neural actions of 5-HT. The slow depolarization associated with an increase in input resistance induced by 5 -HT was readily blocked by 5 -HTP-DP, but the fast depolarization accompanied by a fall in input resistance was blocked less frequently. It is possible that the two actions of $5-\mathrm{HT}$, often seen sequentially in the 
Figure 10. The effect of 5-HTP-DP on the muscarinic response of a type $1 / \mathrm{AH}$ neuron to $\mathrm{ACh}$. The cell was injected with constant depolarizing current pulses. $A$, Pressure microejection of ACh (10 mm, $999 \mathrm{msec}$; arrowhead) evokes a slow depolarization as sociated with a rise in input resistance. During the response several action potentials are evoked when the depolarizing current is injected. $B$, Pressure microejection of 30 drops (999 msec) of 5-HTP-DP (1 mM) does not antagonize the response to $\mathrm{ACh}$; neither did microejection of 5-HTP-DP $(10 \mathrm{~mm})$ or superfusion with $10 \mu \mathrm{M}$ 5-HTP-DP (not illustrated). The resting membrane potential was

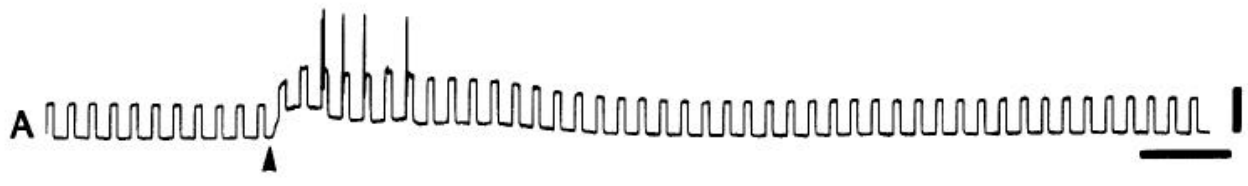

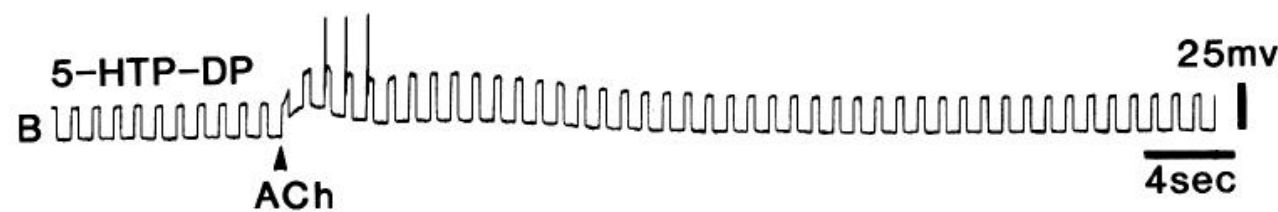
$-80 \mathrm{mV}$.

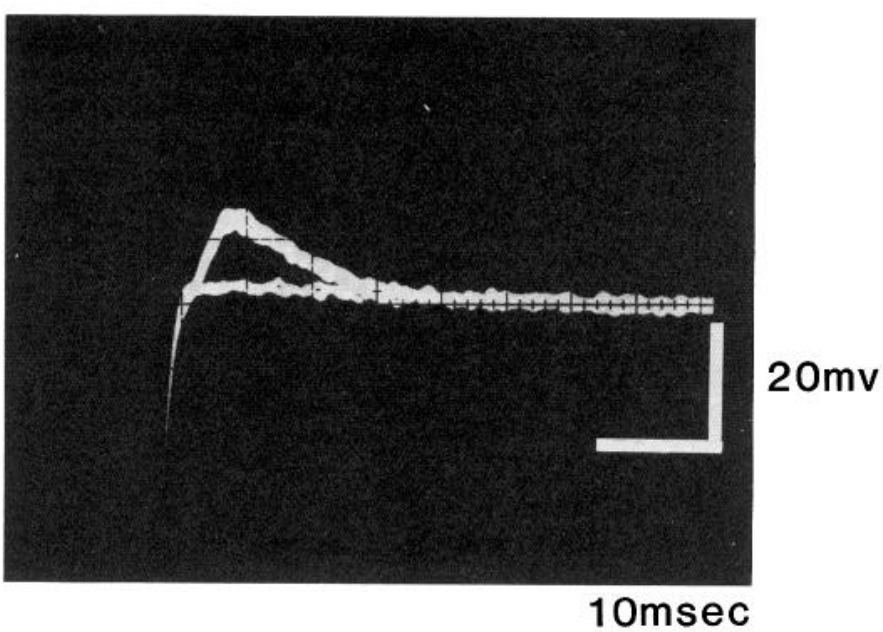

Figure 11. Antagonism of a fast EPSP by hexamethonium. Fast EPSPS were evoked by fiber tract stimulation at $0.5 \mathrm{~Hz}$. The upper tracing shows two superimposed responses. After addition of hexamethonium $(0.1 \mathrm{~mm})$, the response was abolished (lower tracing). This sensitivity to hexamethonium helps to confirm the identity of the nicotinic fast EPSP. The resting membrane potential was $-56 \mathrm{mV}$

same neurons, are mediated by different receptors or a different subtype of the same receptor; however, relatively high concentrations of the dipeptides were necessary to block either effect of 5 HT. When applied by superfusion, a concentration of 1 to $10 \mu \mathrm{M} 5$ HTP-DP was required to antagonize a single threshold pulse of 5 HT (1 mM) ejected from a micropipette. Conceivably, a higher concentration of 5-HTP-DP than was achieved in our experiments might have more consistently blocked the fast depolarization induced by $5-\mathrm{HT}$. The effect of the dipeptides did appear to be concentration dependent; antagonism of the action of 5-HT by 5 HTP-DP could be overcome by applying more $5-\mathrm{HT}$, and the block was reversible by washing. In addition to these postsynaptic actions of 5-HT, the presynaptic action of 5-HT to reduce the amplitude of the fast EPSP in type I/S cells (North et al., 1980) was also antagonized by 5-HTP-DP. The dipeptides of 5 -hydroxytryptophan, therefore, were antagonists of the neural actions of 5-HT. Their effectiveness in this regard is consistent with their potency in inhibiting the binding of ${ }^{3} \mathrm{H}-5-\mathrm{HT}$. 5- $\mathrm{HT}$ is approximately 30 times as potent as 5HTP-DP and 90 times as potent as $N$-hex-5-HTP-DP. This disparity in efficacy probably explains why 10 to 30 drops of pressure microejected 5-HTP-DP (10 mM) are needed to block the action on myenteric neurons of 1 drop of pressure microejected $5-\mathrm{HT}(1 \mathrm{~mm})$.

In contrast to its ability to antagonize effects of 5-HT, 5-HTP-DP did not mimic any of the actions of $5-\mathrm{HT}$ when applied to $5-\mathrm{HT}$ sensitive neurons by microejection, even when given at 300 times the effective amount of 5-HT. 5-HTP-DP, therefore, seems to be only a 5-HT antagonist and seems to have no agonist properties.
Despite the high concentrations of 5-HTP-DP needed to antagonize the effects of 5-HT, the compound appeared at these concentrations to be a relatively specific 5-HT antagonist. 5-HTP-DP did not antagonize the rather similar effects to those of $5-\mathrm{HT}$ on type $\| / \mathrm{AH}$ neurons of substance $\mathrm{P}$ or the muscarinic action of ACh. Moreover, 5-HTP-DP did not affect the amplitude of fast EPSPs in type I/S neurons. The compound, therefore, does not act at substance $P$, nicotinic, or muscarinic receptors and has not been demonstrated to presynaptically inhibit transmitter release.

The slow EPSP evoked in type I/AH neurons by repetitive stimulation of fiber tracts in interganglionic connectives was reversibly antagonized by 5-HTP-DP and N-hex-5-HTP-DP. Since 5-HTP-DP did not block the actions on these cells of substance $P$ or $A C h$, it is unlikely that its action in antagonizing the slow EPSP can be ascribed to blocking the effect of either of these substances. Moreover, there is no evidence to suggest that 5-HTP-DP interferes with transmitter release or has a local anesthetic action; therefore, in view of its ability to block the neural actions of 5-HT, it can be concluded that the ability of 5-HTP-DP to antagonize the slow EPSP supports the hypothesis that $5-\mathrm{HT}$ is a mediator of this response.

Wood and Mayer (1979b) first proposed that the slow EPSP is mediated by $5-\mathrm{HT}$ because $5-\mathrm{HT}$ mimicked the slow EPSP and the slow EPSP was blocked by 5-HT desensitization and by the 5-HT antagonist, methysergide. It soon became apparent that other substances including substance P (Katayama et al., 1979) and ACh (Morita et al., 1982) could also mimic properties of slow synaptic potentials in myenteric neurons. Furthermore, $5-\mathrm{HT}$ has presynaptic effects (North et al., 1980), and it is thus possible that the procedure used to induce 5-HT desensitization prevents the manifestation of a slow EPSP, not by desensitizing postsynaptic 5-HT receptors, but by inhibiting the release of the authentic transmitter. Methysergide, too, is not a specific 5-HT antagonist at $M$ receptors (Drakontides and Gershon, 1968; Costa and Furness, 1979a, b). Methysergide may also reduce the amplitude of the fast EPSP (North et all, 1980; Wood, 1983) and, like 5-HT desensitization, could conceivably be acting presynaptically. Moreover, slow EPSPs can also be antagonized by chymotrypsin, a result interpreted to favor mediation of the response by substance $\mathrm{P}$ or another peptide (Morita et al., 1980; Johnson et al., 1981).

More recently, Bornstein et al. (1984) have studied the effects of interruption of the long fiber pathways of the myenteric plexus on slow EPSPs evoked by focal intraganglionic stimulation. Enteric serotonergic neurons are quite long and project great distances down the gut before they appear to give off terminals (Costa et al., 1981; Furness and Costa, 1982). In contrast, enteric substance $P$ neurons are very short and project extensively within a single ganglion (Costa et al., 1982). Interruption of long pathways, therefore, produces segments of gut that are depleted of 5-HT but which contain substance $P$ (Bornstein et al., 1984). These segments do contain cells that manifest a slow EPSP when that response is elicited by focal intraganglionic stimulation; however, a greater number of shocks must be delivered to evoke a slow EPSP after the 
A

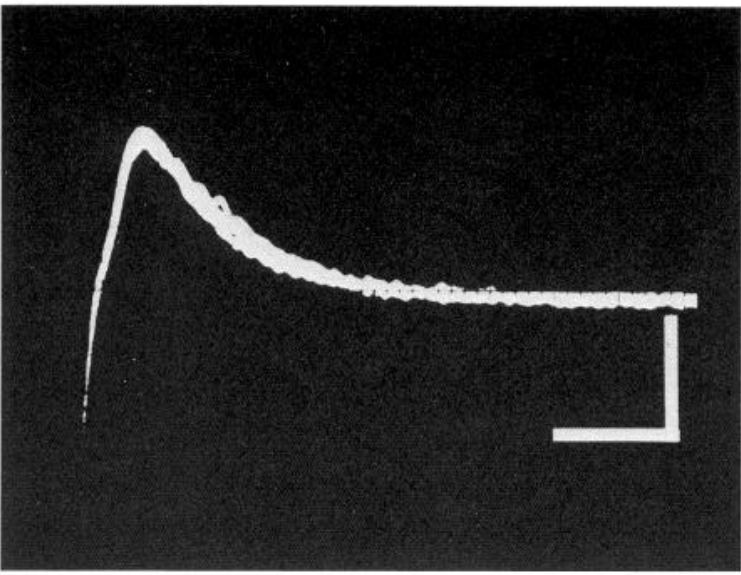

B

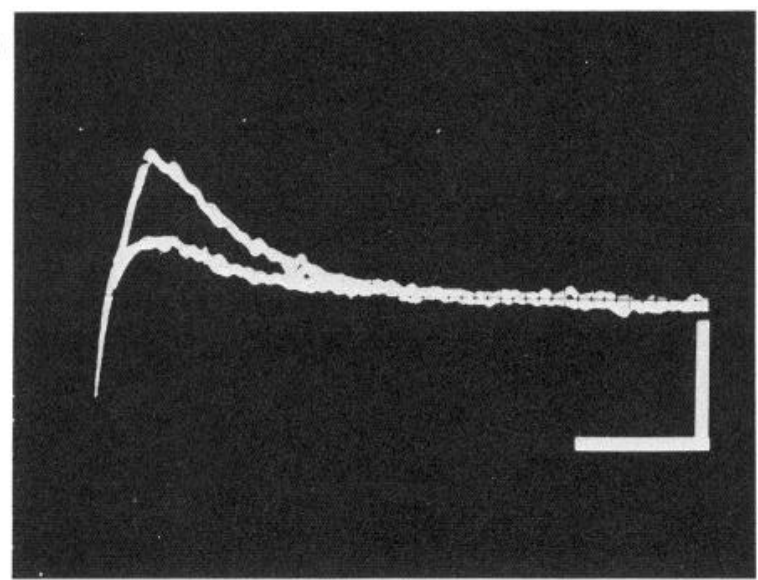

C

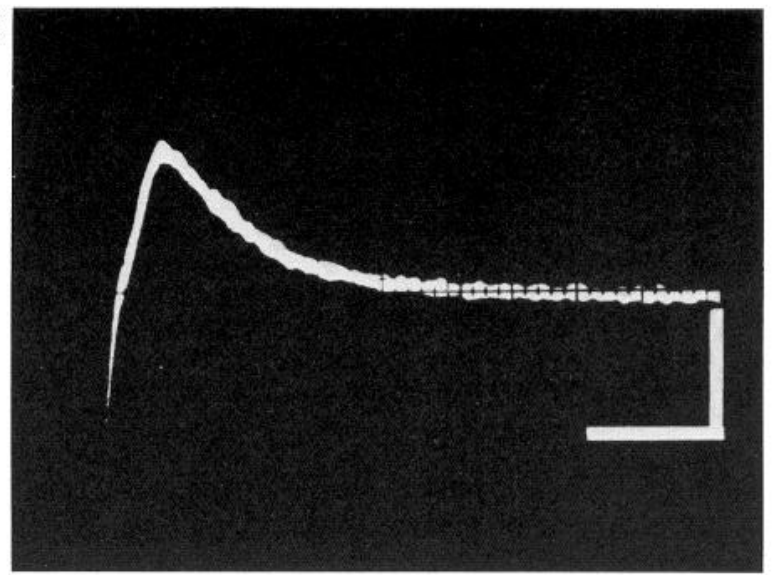

D

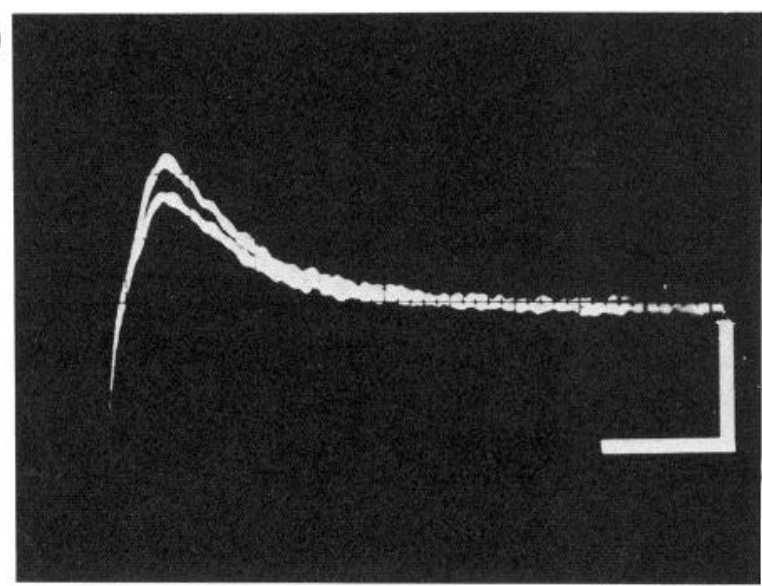

$10 \mathrm{msec}$

Figure 12. Actions and interactions of 5-HT and 5-HTP-DP on fast EPSPs in a type $\mathrm{l} / \mathrm{S}$ cell. The fast EPSPs were evoked by stimulation $(0.5 \mathrm{~Hz})$ of a fiber tract in an interganglionic connective. A, Control. Five fast EPSPs are superimposed. $B$, The amplitude of the fast EPSP (upper trace-two superimposed control responses) is reduced by microejection of 5-HT (1 drop, $800 \mathrm{msec}, 1 \mathrm{~mm}$; lower trace-two superimposed responses in the presence of 5-HT). C, Superfusion with 5-HTP-DP $(10 \mu \mathrm{M})$ does not affect the fast EPSP (five superimposed responses; cf. A). D, The ability of 5-HT to reduce the amplitude of the fast EPSP is antagonized by superfusion with 5-HTP-DP $(10 \mu \mathrm{M})$. Upper trace: In the presence of 5-HTP-DP alone the fast EPSP is similar to that of control. Lower trace: The effect of microejected 5-HT is less than that seen in the absence of 5-HTP-DP; compare with B. This effect of 5-HTP-DP was reversible (not illustrated). The resting membrane potential was $-71 \mathrm{mV}$.

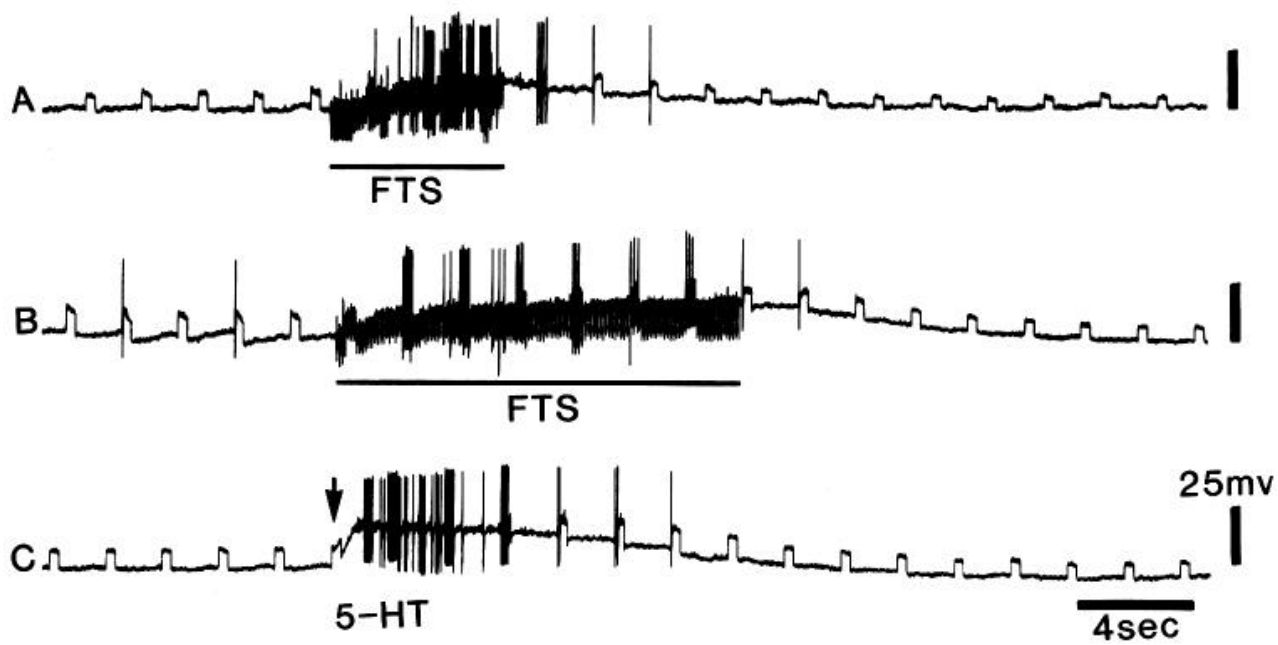

Figure 13. A comparison of the effects of fiber tract stimulation (FTS) and 5-HT on a type II/AH neuron. The neuron was injected with constant depolarizing current pulses through the recording micropipette. $A$, Fiber tract stimulation $(10 \mathrm{~Hz})$ induces a slow EPSP. During this response input resistance increases, the cell spikes repetitively throughout the pulses of depolarizing current injection (amplitude of spikes is distorted by pen recorder), and somal spikes are elicited. $B$, Fiber tract stimulation for a longer time induces a more prolonged response. C, Microejection of 5-HT (1 pulse, $10 \mathrm{~mm}, 300 \mathrm{msec}$ ) induces a slow depolarization associated with increased input resistance and enhanced excitability of the cell that mimics the slow EPSP. The resting membrane potential was $-71 \mathrm{mV}$. 


\section{FTS FTS 4

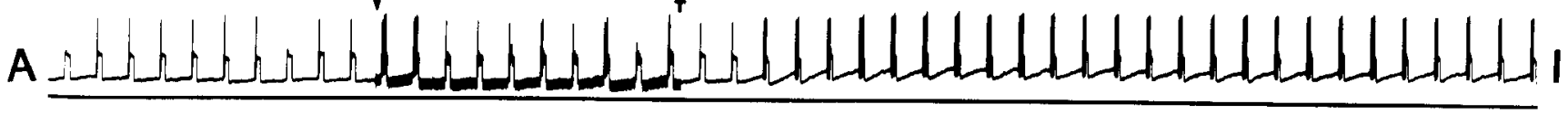

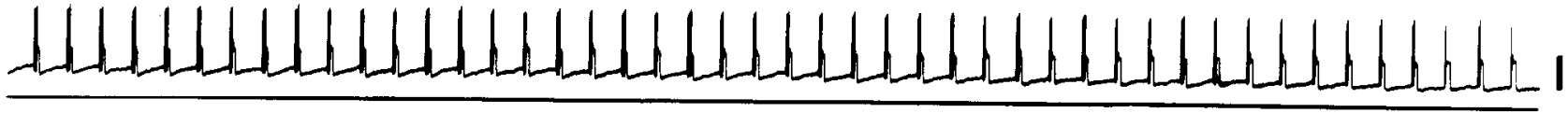
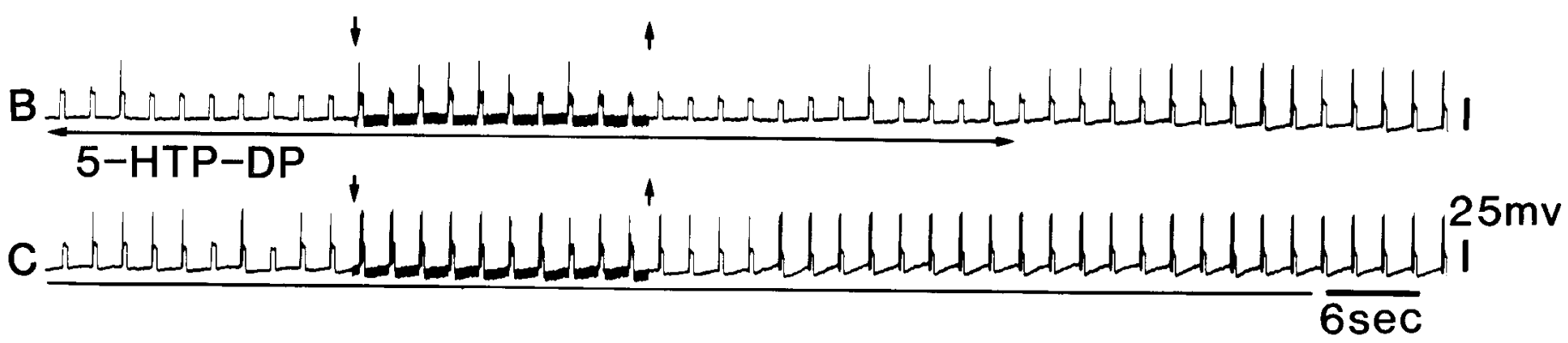

Figure 14. Antagonism of the slow EPSP in a type H/AH neuron by superfusion with 5-HTP-DP. A, Stimulation of an interganglionic fiber tract (between arrows) induces a very long lasting slow EPSP. Note the prolonged depolarization and repetitive spiking elicited by injection of constant depolarizing current pulses during the slow EPSP, $B$, The slow EPSP produced by fiber tract stimulation is attenuated by microejection (horizontal arrows) of 5-HTP-DP ( 30 pulses, $999 \mathrm{msec}, 10 \mathrm{~mm}$ ). C, The slow EPSP recovers after 5-HTP-DP has been washed out. The resting membrane potential was $-67 \mathrm{mV}$.

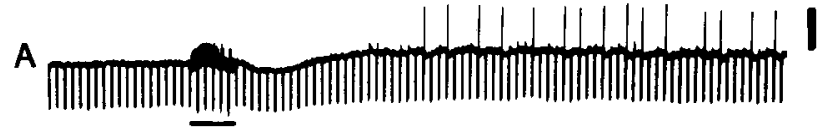

$\mathbf{B}$
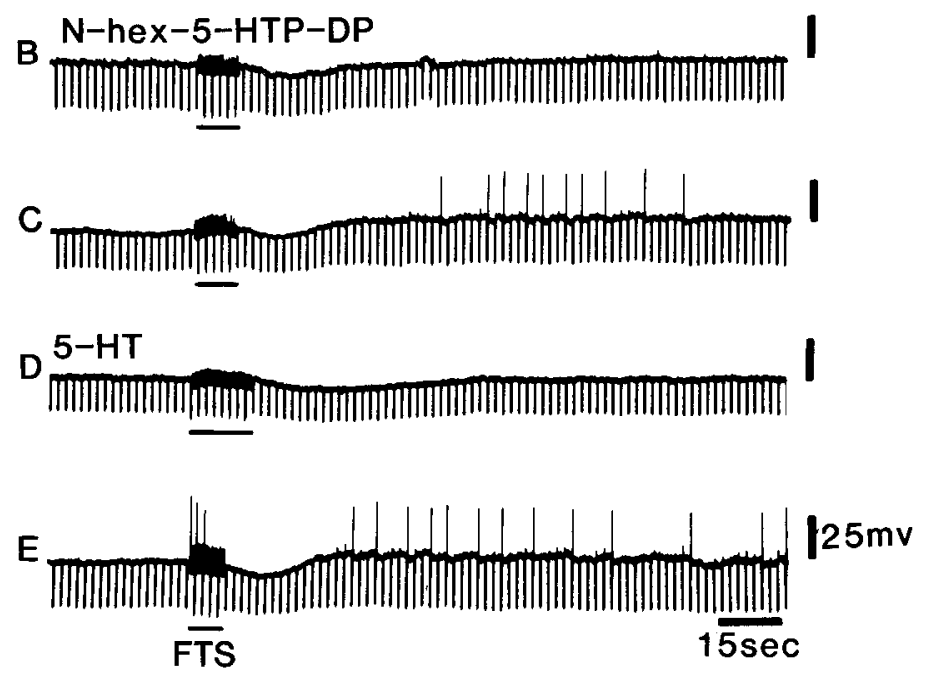

Figure 15. Antagonism of slow EPSPs in a type II/AH neuron by superfusion with 5-HTP-DP and by desensitization to 5-HT. The cell was injected with constant hyperpolarizing current pulses through the recording micropipette. $A$, Control response. Stimulation of a fiber tract in an interganglionic connective (horizontal line; $10 \mathrm{~Hz}$ ) induces an initial hyperpolarizing response associated with a decreased input resistance followed by the slow EPSP. During the slow EPSP input resistance is increased and action potentials are evoked by anodal break excitation. $B$, Superfusion with $N$-hex-5-HTP-DP $(10$ $\mu \mathrm{M})$ blocks the slow EPSP but not the initial hyperpolarization induced by fiber tract stimulation. C, Following washout of N-hex-5-HTP-DP the slow EPSP recovers. $D$, Desensitization by superfusion with $10 \mu \mathrm{M} 5-\mathrm{HT}$ blocks the slow EPSP but, as with $N$-hex-5-HTP-DP, does not antagonize the initial hyperpolarizing response to fiber tract stimulation. $E$, Following washout of 5-HT the slow EPSP recovers. During the experiment the resting membrane potential changed from -52 to $-64 \mathrm{mV}$.

long pathways have been eliminated (Bornstein et al., 1984). These results indicate that $5-\mathrm{HT}$ is not the only mediator of slow EPSPS evoked by focal intraganglionic stimulation in the myenteric plexus because a slow EPSP can be obtained in the absence of $5-\mathrm{HT}$. Conversely, the greater difficulty encountered in evoking the response when 5-HT is depleted suggests that it may contribute even to the response evoked by focal intraganglionic stimulation.

It should be noted that there are significant differences between investigators in the means employed to evoke slow EPSPS. One method is to utilize stimulation of fiber tracts in interganglionic connectives (Wood and Mayer, 1979a); the other is to use focal intraganglionic stimulation (Johnson et al., 1980a). Because enteric serotonergic neurons are long and substance $P$ neurons are short (Costa et al., 1981, 1982; Furness and Costa, 1982), stimulation of interganglionic connectives would be expected to activate relatively more serotonergic axons than those containing substance P. However, stimulation of discrete foci within a ganglion would be expected to be more likely to activate substance $\mathrm{P}$-containing neurites which ramify profusely within a ganglion than would the serotonergic axons which are much less numerous and tend to be dispersed within ganglia. These differences in stimulation may account for apparently discrepant results concerning slow synaptic potentials reported by different investigators. For example, those groups that have used focal intraganglionic stimulation have found slow EPSPs in both type I/S and type II/AH cells (Johnson et al., 1980a; North and Tokimasa, 1982; Bornstein et al., 1984). In addition, focal intraganglionic stimulation can evoke muscarinic slow EPSPs in type $\mathrm{l} / \mathrm{S}$ cells with single shock stimuli (North and Tokimasa, 1982). In contrast, when interganglionic connectives are stimulated, slow EPSPs can be evoked only in type II/AH neurons (Wood and Mayer, 1979a; Grafe et al., 1980; Wood, 1981, 1983; Erde et al., 1984), the slow EPSPS are entirely resistant to muscarinic blockade (Wood and Mayer, 1979b), and repetitive stimulation is required to evoke the response (Wood and Mayer, 1979a). It seems likely, therefore, that focal intraganglionic stimulation and stimulation of interganglionic connectives activate different inputs to myenteric ganglion cells. It is thus possible that similar slow synaptic responses may be evoked by different inputs utilizing different neurotransmitters. Conceivably, ACh (at least in type I/S cells), substance $P$, and $5 \cdot H T$ all may be mediators of this type of response.

In the current investigation, the hypothesis of Wood and Mayer (1979b) that 5 -HT is a mediator of slow EPSPs was tested. The 
method (fiber tract stimulation) of evoking a slow EPSP that was used was, therefore, chosen to be similar to that of Wood and Mayer (1979b). Moreover, this method also seemed most reasonable because it had, as mentioned above, the best chance of activating the serotonergic inputs to myenteric ganglia. Since we found that the specific 5-HT M receptor antagonist, 5-HTP-DP, was always effective in inhibiting the slow EPSPs evoked by fiber tract stimulation, it seems likely that the serotonergic innervation is probably responsible for mediating many, if not all, of these responses. Thesc observations correlate extremely well with those of Erde et al. (1984), who radioautographically identified the serotonergic inputs to physiologically characterized myenteric neurons. Slow EPSPs in that study were also evoked by stimulation of interganglionic fiber tracts. Slow EPSPs wcre found only in type I/AH neurons, and these were marked for later electron microscopic study by injection of horseradish peroxidase. Subsequently, the tissues were incubated with ${ }^{3} \mathrm{H}-5$ $\mathrm{HT}$ under conditions in which ${ }^{3} \mathrm{H}-5-\mathrm{HT}$ was taken up only into serotonergic axons. Examination of serial electron microscopic radioautographs revealcd that every cell that demonstrated a slow EPSP received serotonergic synapses but that such synapses were rare on neurons that did not show a slow EPSP. Both the study of Erde et al. (1984) and the current investigation are compatible with the view that fiber tract stimulation preferentially evokes slow EPSPs in typc I//AH ncurons by activating scrotonergic axons; all such effects are blocked by antagonists (5-HTP-DP and N-hex-5-HTP-DP) of the neural actions of 5-HT, and serotonergic synapses are actually found on all cells that show the response. The experiments of Bornstein et al. (1984) in which long fiber tracts were cut surgically did not test the role of $5 \mathrm{HT}$ in mediating slow EPSPs cvoked by stimulation of long fiber tracts in interganglionic connectives. Born stein et al. (1984) used focal intraganglionic stimulation and stimulated the short projections between the lesion and the cell they recorded from. Although their results do, as noted earlier, clearly establish that $5-\mathrm{HT}$ cannot be the only transmitter mediating a slow EPSP, it seems reasonable to conclude that $5-\mathrm{HT}$ is one such mediator, probably of long tract neurons. Fiber tract stimulation evokes other effects besides slow EPSPs in myenteric neurons. There is also, for example, a slow inhibitory postsynaptic potential ( $\Gamma$ ig. 17 in Johnson et al., 1980a) that is not antagonized by 5 -HTPDP or desensitization to 5-HT. These other effects are probably not mediated by 5 -HT

In conclusion, the current experiments support the hypothesis that enteric high affinity ${ }^{3} \mathrm{H}-5-\mathrm{HT}$ binding sites are $5-\mathrm{HT} \mathrm{M}$ receptors. They also support the hypothesis that $5-\mathrm{HT}$ is a neurotransmitter that mediates slow EPSPS in type II/AH neurons evoked by activation of fibers in interganglionic connectives of the myenteric plexus.

\section{References}

Bennett, J. P., Jr., and S. H. Snyder (1976) Serotonin and lysergic acid diethylamide binding in rat brain membranes: Relationship to postsynaptic serotonin receptors. Mol. Pharmacol. 12: 373-389.

Bornstein, J., R. A. North, M. Costa, and J. B. Furness (1984) Excitatory synaptic potentials due to activation of neurons with short projection in the myenteric plexus. Neıroscience 11: 723-731.

Branchek, T., M. Kates, and M. D. Gershon (1984) Enteric receptors for 5hydroxytryptamine. Brain Res., 324: 107-118.

Brownlee, G., and E. S. Johnson (1963) The site of the action of 5 hydroxytryptamine receptor on the intramural nervous plexus of the guineapig isolated ileum. Br. J. Pharmacol. 21: 306-322.

Bülbring, E., and A. Crema (1958) Observations concerning the action of 5 hydroxytryptamine on the peristaltic reflex. Br J. Pharmacol. 13: 444-457.

Bülbring, E., and R. C. Y. Lin (1958) The effect of intraluminal application of 5-hydroxytryptamine and 5-hydroxytryptophan on peristalsis: The local production of $5-\mathrm{HT}$ and its release in relation to intraluminal pressure and propulsive activity. J. Physiol. (Lond.) 140: 381-407.

Costa, M., and J. B. Furness (1979a) Commentary: On the possibility that an indoleamine is a neurotransmitter in the gastrointestinal tract. Biochem. Pharmacol. 28: 565-571.

Costa, M., and J. B. Furness (1979b) The sites of action of 5-hydroxytrypta- mine in nerve muscle preparations from the guinea-pig small intestine and colon. Br. J. Pharmacol. 65: 237-248

Costa, M., J. B. Furness, I. J. Llewellyn-Smith, and A. C. Cuello (1981) Projections of substance P-containing neurons within the guinea-pig small intestine. Neuroscience 6: 411-424.

Costa, M., J. B. Furness, A. C. Cuello, A. A. J. Verhofstad, H. W. J. Steinbusch, and R. P. Elde (1982) Neurons with 5-hydroxytryptamine-like immunoreactivity in the enteric nervous system: Their visualization and reactions to drug treatment. Neuroscience $7: 351-363$.

Drakontides, A. B., and M. D. Gershon (1968) 5-Hydroxytryptarnine receplors in the mouse duodenum. Br. J. Pharmacol. Chemother. 33: 480-492.

Erde, S. M., D. Sherman, and M. D. Gershon (1984) Serotonin: Location in terminals on identified myenteric neurons where it mimics a slow excitatory postsynaptic potential (EPSP). In IUPHAR Ninth International Congress of Pharmacology Abstracts, Macmillan Press Ltd., London. p. 1598P.

Fozard, J. R., and A. T. M. Mobarok Ali (1978) Receptors for 5-hydroxytryptamine on the sympathetic nerves of the rabbit heart. Naunyn-Schmiedeberg's Arch. Pharmacol. 301: 223-235.

Fuller, R. W. (1984) Serotonin receptors. In Neuroreceptors in Health and Disease, J. Marwaha and W. J. Anderson, eds., pp. 158-181, S. Karger AG, Basel.

Furness, J. B., and M. Costa (1982) Neurons with 5-hydroxytrptamine-like immunoreactivity in the enteric nervous system: Their projections in the guinea-pig small intestine. Neuroscience 7: 341-349.

Gaddum, J. H., and Z. P. Picarelli (1957) Two kinds of tryptamine receptor Br. J. Pharmacol. 12: 323-328

Gershon, M. D., T. Branchek, M. Takaki, S. M. Erde, and H. Tamir. (1984a) Enteric serotonin (5-HT) receptors. In IUPHAR Ninth International Congress of Pharmacology Abstract, Macmillan Press Ltd., London. p. 1599P

Gershon, M. D., M. Takaki, H. Tamir, and T. Branchek (1984b) The enteric neural receptor for 5-hydroxytryptamine. Experentia, in press.

Grafe, P., C. J. Mayer, and J. D. Wood (1980) Synaptic riodulation of calcium-dependent potassium conductance in myenteric neurons in the guinea pig. J. Physiol. (Lond.) 305: 235-248

Gyermek, L. (1966) Drugs which antagonize 5-hydroxytryptamine and related indolealkylamines. In Handbuch der experimentellen Pharmakologie, V. Erspamer, ed., Vol. XIX, pp. 471-528, Springer-Verlag, Berlin.

Hirst, G. D. S., and E. M. Silinsky (1975) Some effects of 5-hydroxytryptamine dopamine and noradrenaline on neurons in the submucous plexus of guinea-pig small intestine. J. Physiol. (Lond.) 251: 817-832.

Hirst, G. D. S., M. E. Holman, and I. Spence (1974) Two types of neurones in the myenteric plexus of duodenum in the guinea-pig. J. Physiol. (Lond.) 236: $303-326$

Holman, M. E., H. D. S. Hirst, and I. Spence (1972) Preliminary studies of the neurons of Auerbach's plexus using intracellular microelectrodes. Aust. J. Exp. Biol. Med. 50: 795-801.

Johnson, S. M., Y. Katayama, and R. A. North (1980a) Slow synaptic potentials in neurons of the myenteric plexus. J. Physiol. (Lond.) 301 505-516.

Johnson, S. M., Y. Katayama, and R. A. North (1980b) Multiple actions of 5 hydroxytryptamine on myenteric neurones of the guinea-pig ileum. J. Physiol. (Lond.) 304: 459-470.

Johnson, S. M., Y. Katayama, K. Morita and R. A. North (1981) Mediators of slow symaptic potentials in the myenteric plexus of the yuinea-pig ileum. J. Physiol. (Lond.) 320: 175-186.

Katayama, $Y$., and R. A. North (1978) Does substance $P$ mediate slow synaptic excitation within the myenteric plexus? Nature 274: 387-388.

Katayama, Y, R. A. North, and J. T. Williams (1979) The action of substance $P$ on neurones of the myenteric plexus of the guinea-pig small intestine. Proc. R. Soc. Lond. (Biol.) 206: 191-208

Leysen, J. E., C. J. E. Niemegeers, J. M. Van Nueten, and P. M. Laduron (1982) $\left[{ }^{3} \mathrm{H}\right]$ Ketanserin (R41468), a selective ${ }^{3} \mathrm{H}$-ligand for serotonin receptor binding sites. Binding properties, brain distribution, and functional role. Mol. Pharmacol. 21: 301-314.

Morita, K., R. A. North, and Y. Katayama (1980) Evidence thal subslarice P is a neurotransmitter in the myenteric plexus. Nature 287: 151-152.

Morita, K., R. A. North, and T. Tokimasa (1982) Muscarinic agonists inactivate potassium conductance of guinea-pig myenteric neurones. J. Physiol. (Lond.) 333: 125-139.

Nelson, D. L., N. W. Pedigo, and H. I. Yamamura (1981) Multiple ${ }^{3} \mathrm{H}-5-$ hydroxytryptamine binding sites in rat brain. J. Physiol. (Paris) 77: 369 372

Nishi, S., and R. A. North (1973) Intracellular recording from the myenteric plexus of the guinea-pig ileum. J. Physiol. (Lond.) 231: 471-491. 
North, R. A., and T. Tokimasa (1982) Muscarinic synaptic potentials in guineapig myenteric plexus neurones. J. Physiol. (Lond.) 333: 151-156.

North, R. A., G. Henderson, Y. Katayama, and S. M. Johnson (1980) Electrophysiological evidence for presynaptic inhibition of acetylcholine release by 5 -hydroxytryptamine in the enteric nervous system. Neuroscience 5: 581-586.

Paton, W. D. M. (1957) The action of morphine and related substances on contraction and on acetylcholine output of coaxially stimulated guinea-pig ileum. Br. J. Pharmacol. 12: 119-127.

Pedigo, N. W., H. I. Yamamura, and D. L. Nelson (1981) Discrimination of multiple $\left[{ }^{3} \mathrm{H}\right] 5$-hydroxytryptamine binding sites by the neuroleptic spiperone in rat brain. J. Neurochem. 36: 220-226.

Peroutka, S. J., and S. H. Snyder (1979) Multiple serotonin receptors: Differential binding of $\left[{ }^{3} \mathrm{H}\right] 5$-hydroxytryptamine, $\left[{ }^{3} \mathrm{H}\right]$ lysergic acid diethylamide and [ $\left[{ }^{3} / 1\right]$ spiroperidol. Mol. Pharmacol. 16: 687-699.

Schaumann, W. (1957) Inhibition by morphine of the release of acetylcholine from the intestine of the guinea pig. Br. J. Pharmacol. 12: 115-118.

Takaki, M., T. Branchek, H. Tamir, and M. D. Gershon (1984) Specific antagonism of enteric neural serotonin receptors by $\mathrm{N}$-acetyl-5-hydroxy- tryptophyl-5-hydroxytryptophan amide (5-HTP-DP). Digest. Dis. Sci. 29: 553.

Tamir, H., and M. Wilchek (1979) 5-Hydroxytryptophyl peptides: Potent inhibitors of a storage compartment of serotonin. J. Neurochem. 32: 593598

Tamir, H., S. E. Karpiak, I. J. Wajda, M. Wilchek, and R. J. Bodner (1979) Analgesic effects of $\mathrm{N}$-acetyl-5HTP-5HTP amide are not directly related to brain serotonin levels. Life Sci. 25: 655-664.

Vizi, V. A., and E. S. Vizi (1978) Direct evidence for acetylcholine releasing effect of serotonin in the Auerbach plexus. J. Neural Transm. 42: 127138.

Wood, J. D. (1981) Physiology of the enteric nervous system. In Physiology of the Gastrointestinal Tract, L. R. Johnson, ed., pp. 1-37, Raven Press, New York.

Wood, J. D. (1983) Neurophysiology of parasympathetic and enteric ganglia. In Autonomic Ganglia, L.-G. Elvin, ed. pp. 367-398, John Wiley \& Sons, Inc., New York.

Wood, J. D., and C. J. Mayer (1979a) Intracellular study of tonic-type enteric neurons in guinea pig small intestine. J. Neurophysiol. 42: 569-581.

Wood, J. D., and C. J. Mayer (1979b) Serotonergic activation of tonic-type enteric neurons in guinea pig small bowel. J. Neurophysiol. 42: 582-593. 